\title{
WAVE CONDITIONS FOR TWO PHASES OF HARBOR DEVELOPMENT IN LOS ANGELES OUTER HARBOR, LOS ANGELES, CALIFORNIA
}

\section{Coastal Model Investigation}

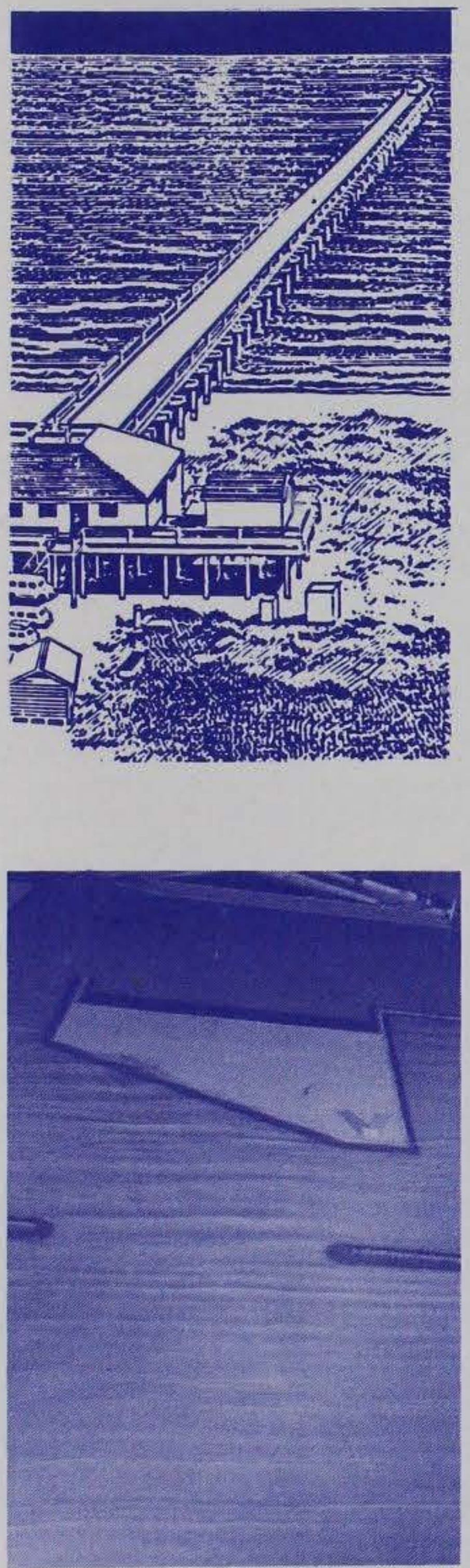

by

Robert R. Bottin, Jr., Hugh F. Acuff

Coastal Engineering Research Center

DEPARTMENT OF THE ARMY

Waterways Experiment Station, Corps of Engineers

3909 Halls Ferry Road, Vicksburg, Mississippi 39180-6199

\section{US-CE-C propenty of the UNITED STATES GOVERNMENT}

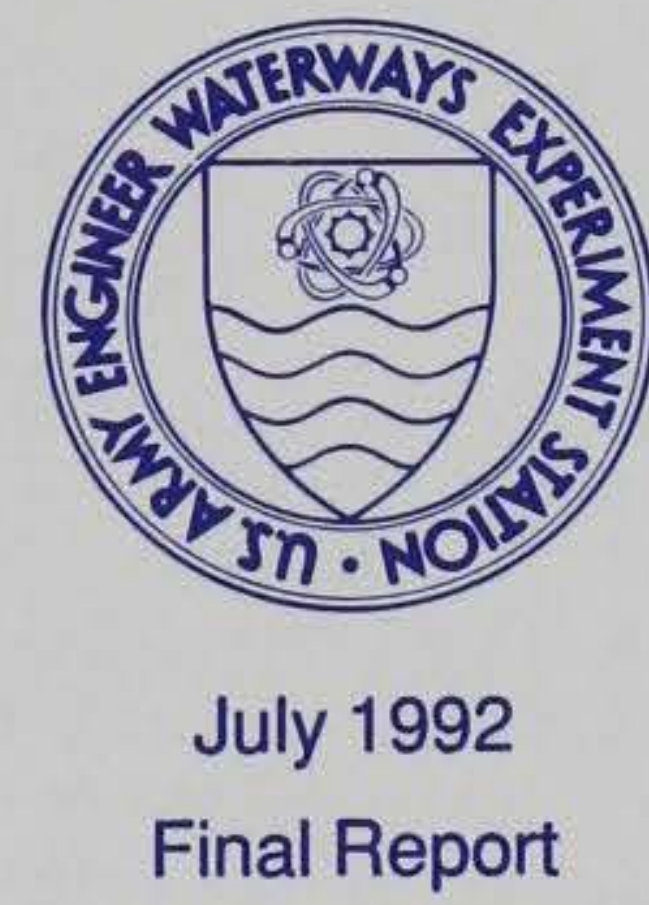

Approved For Public Release; Distribution Is Unlimited

\author{
RESEARCH LIBRARY \\ US ARMY ENGINEER WATERWAYS \\ EXPERIMENT STATION \\ VICKSBURG, MISSISSIPP!
}

Prepared for US Army Engineer District, Los Angeles

Los Angeles, California 90053-2325

and

Port of Los Angeles, Harbor Department

San Pedro, California 90733-0151 


\section{REPORT DOCUMENTATION PAGE}

Public reporting burden for this collection of information is estimated to average 1 hour per response, including the time for reviewing instructions, searching existing data sources,

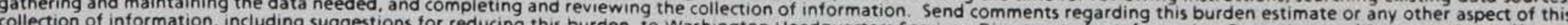
Davis Highway, Suite 1204, Arlington, VA 22202-4302, and to the Office of Management and Budget, Paperwork Reduction Project (0704-0188), Washington, DC 20503.

\section{\begin{tabular}{l|l|l} 
1. AGENCY USE ONLY (Leave blank) & 2. REPORT DATE & 3. REPORT TYPE AND DATES COVERED
\end{tabular}}

4. TITLE AND SUBTITLE

July 1992

Final Report

Wave Conditions for Two Phases of Harbor Development

in Los Angeles Outer Harbor, Los Angeles, California:

Coastal Model Investigation

6. AUTHOR(S)

Robert R. Bottin, Jr., and Hugh F. Acuff

7. PERFORMING ORGANIZATION NAME(S) AND ADDRESS(ES)

USAE Waterways Experiment Station

Coastal Engineering Research Center

3909 Halls Ferry Road

Vicksburg, MS 39180-6199

9. SPONSORING/MONITORING AGENCY NAME(S) AND ADDRESS(ES)

USAED, Los Angeles

PO Box 2711

Los Angeles, CA 90053-2325
Port of Los Angeles

Harbor Department

San Pedro, CA 90733-0151

\section{SUPPLEMENTARY NOTES}

Available from National Technical Information Service, 5285 Port Royal Road, Springfield, VA 22161

12a. DISTRIBUTION/AVAILABILITY STATEMENT

12b. DISTRIBUTION CODE

Approved for public release; distribution is unlimited

\section{ABSTRACT (Maximum 200 words)}

A physical model study, using a 1:100 scale (undistorted) hydraulic model of Los Angeles Outer Harbor, California, was conducted to investigate shortperiod storm wave conditions for proposed harbor development located near the Angel's Gate entrance. The model reproduced the proposed harbor expansion, Angel's Gate entrance, portions of the existing breakwaters, and sufficient bathymetry in San Pedro Bay to permit proper reproduction of the required test waves. The model then was reactivated to determine the optimum plan for protection of the south mooring area from locally generated waves in the harbors complex if the adjacent Port of Long Beach and/or the Pactex landfills are not constructed initially. Finally, tests reported herein describe wave conditions in various mooring areas during phases of construction. An $80-\mathrm{ft}$-long electrohydraulic, unidirectional, spectral wave generator and an automated data acquisition and control system were used in model operation. It was concluded from results of these tests that:

\begin{tabular}{|c|c|c|c|}
\hline \multicolumn{3}{|l|}{ 14. SUBJECT TERMS } & $\begin{array}{l}\text { 15. NUMBER OF PAGES } \\
53\end{array}$ \\
\hline \multicolumn{3}{|l|}{ See reverse. } & 16. PRICE CODE \\
\hline $\begin{array}{l}\text { 17. SECURITY CLASSIFICATION } \\
\text { OF REPORT } \\
\text { UNCLASSIFIED } \\
\end{array}$ & $\begin{array}{l}\text { 18. SECURITY CLASSIFICATION } \\
\text { OF THIS PAGE } \\
\text { UNCLASSIFIED }\end{array}$ & $\begin{array}{l}\text { 19. SECURITY CLASSIFICATION } \\
\text { OF ABSTRACT }\end{array}$ & 20. LIMITATION OF ABSTRACT \\
\hline NSN $7540-01-280-5500$ & & & $\begin{array}{l}\text { andard Form } 298 \text { (Rev. 2-89) } \\
\text { scribed by ANSI std. } 239-18 \\
3-102\end{array}$ \\
\hline
\end{tabular}


13. (Concluded).

a. As tested, the originally proposed first phase of construction (Plan 1) will result in wave heights well within the established criteria of $2.5 \mathrm{ft}$ in the dry bulk terminal and $1.5 \mathrm{ft}$ in the container terminal for locally generated waves within the harbors complex.

b. A total of $3,000 \mathrm{ft}$ of breakwater length can be removed from the first phase of construction ( $P 1$ an 11) and the established wave height acceptance criteria will still be met for locally generated wind waves.

c. The Plan 11 alternative of the first phase of construction $(3,000 \mathrm{ft}$ of breakwater removed) will provide adequate wave protection to the berthing areas during periods of storm wave attack incident from deep water.

d. The second phase of construction (Plan 14) will provide adequate wave protection to the berthing areas during periods of storm wave attack incident from deep water.

14. (Concluded).

Breakwaters

Harbors, California

Hydraulic Models
Los Angeles and Long Beach Harbors, California

Short-period storm waves

Wave protection 
A request for additional testing on the existing Los Angeles Outer Harbor model was initiated by the Port of Los Angeles in coordination with the US Army Engineer District (USAED), Los Angeles. Authorization for the US Army Engineer Waterways Experiment Station (WES), Coastal Engineering Research Center (CERC), to perform the study was subsequently granted by Headquarters, US Army Corps of Engineers. Funds were provided by the Port of Los Angeles and authorized by USAED, Los Angeles, on 2 July 1990.

Model testing was conducted at WES during the period February-July 1991 by personnel of CERC under the direction of Dr. James R, Houston and Mr. Charles C. Calhoun, Jr., Director and Assistant Director, CERC, respectively; and under direct supervision of Messrs. C. E. Chatham, Jr., Chief, Wave Dynamics Division, and Dennis G. Markle, Chief, Wave Processes Branch (WPB). The tests were conducted by Mr. Hugh F. Acuff, Civil Engineering Technician, and Mr. William G. Henderson, Computer Technician, under the supervision of Mr. Robert R. Bottin, Jr., Project Manager. This report was prepared by Messrs. Bottin and Acuff and typed by Ms. Debbie S. Fulcher, WPB.

During the course of the investigation, liaison was maintained by means of conferences and telephone communications. Messrs. John Warwar and Dick Wittkop, Port of Los Angeles, visited WES to observe model operation and participate in a conference.

Initial test results from the model study were reported in WES Technical Report CERC-89-13, "Wave Conditions for Proposed Harbor Development in Los Angeles Outer Harbor, Los Angeles, California; Coastal Model Investigation," dated December 1989. Test results for additional wave conditions then were reported in WES Technical Report CERC-91-4, "Wave Conditions for Proposed Harbor Development in Los Angeles Outer Harbor, Los Angeles, California, Supplemental Tests; Coastal Model Investigation," dated May 1991. Test results for two phases of harbor development in Los Angeles Outer Harbor are reported herein.

At the time of publication of this report, Dr. Robert $W$. Whalin was Director of WES, COL Leonard G. Hasse11, EN, was Commander and Deputy Director. 
PREFACE

CONVERSION FACTORS, NON-SI TO SI (METRIC)

UNITS OF MEASUREMENT . . . . . . . . . . . . . . . . . . . . . . . . . . 3

PART I: INTRODUCTION . . . . . . . . . . . . . . . . . . . . . 4

Background . . . . . . . . . . . . . . . . . . . . 4

Model Study Objectives . . . . . . . . . . . . . . . . . . . . 5

Previously Reported Model Tests and Conclusions . . . . . . . . . . 6

Purpose of Current Investigation . . . . . . . . . . . . . . . . . 8

Wave-Height Criteria . . . . . . . . . . . . . . . . . . . . . . 8

PART II: MODEL ......................... . . . 9

Design of Model . . . . . . . . . . . . . . . . . . . . . . . . . . 9

Mode1 and Appurtenances . . . . . . . . . . . . . . . . . . . . . . 11

PART III: TEST CONDITIONS AND PROCEDURES . . . . . . . . . . . . . . . . . . 14

Selection of Test Conditions . . . . . . . . . . . . . . . . . . . . 14

Analysis of Model Data . . . . . . . . . . . . . . . . . . . . . . . 17

PART IV: TESTS AND RESULTS . . . . . . . . . . . . . . . . . . . . . . . 19

Tests . . . . . . . . . . . . . . . . . . . 19

Test Results . . . . . . . . . . . . . . . . . . . . . . . . . . 21

PART V: CONCLUSIONS . . . . . . . . . . . . . . . . . . . . . . . . . . 23

REFERENCES . . . . . . . . . . . . . . . . . . . . . . . . . . . 24

TABLES $1-7$

PHOTOS 1-16

PLATES 1-3 


\section{CONVERSION FACTORS, NON-SI TO SI (METRIC)}

- UNITS OF MEASUREMENT

Non-SI units of measurement used in this report can be converted to SI (metric) units as follows:

Multiply

acres

degrees (angle)

feet

miles (US statute)

square feet

square miles
By

4046.873

0.01745329

0.3048

1.609347

0.09290304

2.589998
To Obtain

square metres

radians

metres

kilometres

square metres

square kilometres 
WAVE CONDITIONS FOR TWO PHASES OF HARBOR DEVELOPMENT IN LOS ANGELES

OUTER HARBOR, LOS ANGELES, CALIFORNIA

\section{Coastal Model Investigation}

PART I: INTRODUCTION

\section{Background}

1. The ports of Los Angeles and Long Beach are located in San Pedro Bay along the southern coast of California (Figure 1). Historically, they have experienced long-period surge activity which occasionally results in mooring difficulties for ships berthed in various locations within the harbors complex. In coordination with the US Army Corps of Engineers (Corps), the Ports of Los Angeles and Long Beach are conducting studies for harbor development and expansion to accommodate future needs. Descriptions of the existing breakwaters may be found in Bottin (1988).



Figure 1. Project location 
2. A distorted model (scale, 1:400 horizontal, $1: 100$ vertical) of the Los Angeles-Long Beach Harbors complex was designed and constructed at the US Army Engineer Waterways Experiment Station (USAEWES) in the early 1970's and has been used since that time to determine the effects of long-period waves (30 to $400 \mathrm{sec}$ ) which lead to resonant harbor oscillations that can cause ship loading-unloading problems and downtime. The model distortion and scales, however, make the model inappropriate for short-period ( 3 to $25 \mathrm{sec}$ ) wind wave testing.

\section{Model Study Objectives}

3. At the request of the Port of Los Angeles, in coordination with the US Army Engineer District, Los Angeles (SPL) an undistorted hydraulic model, which includes a portion of Los Angeles Outer Harbor (Figure 2), was designed and constructed by the WES Coastal Research Center (CERC) to:

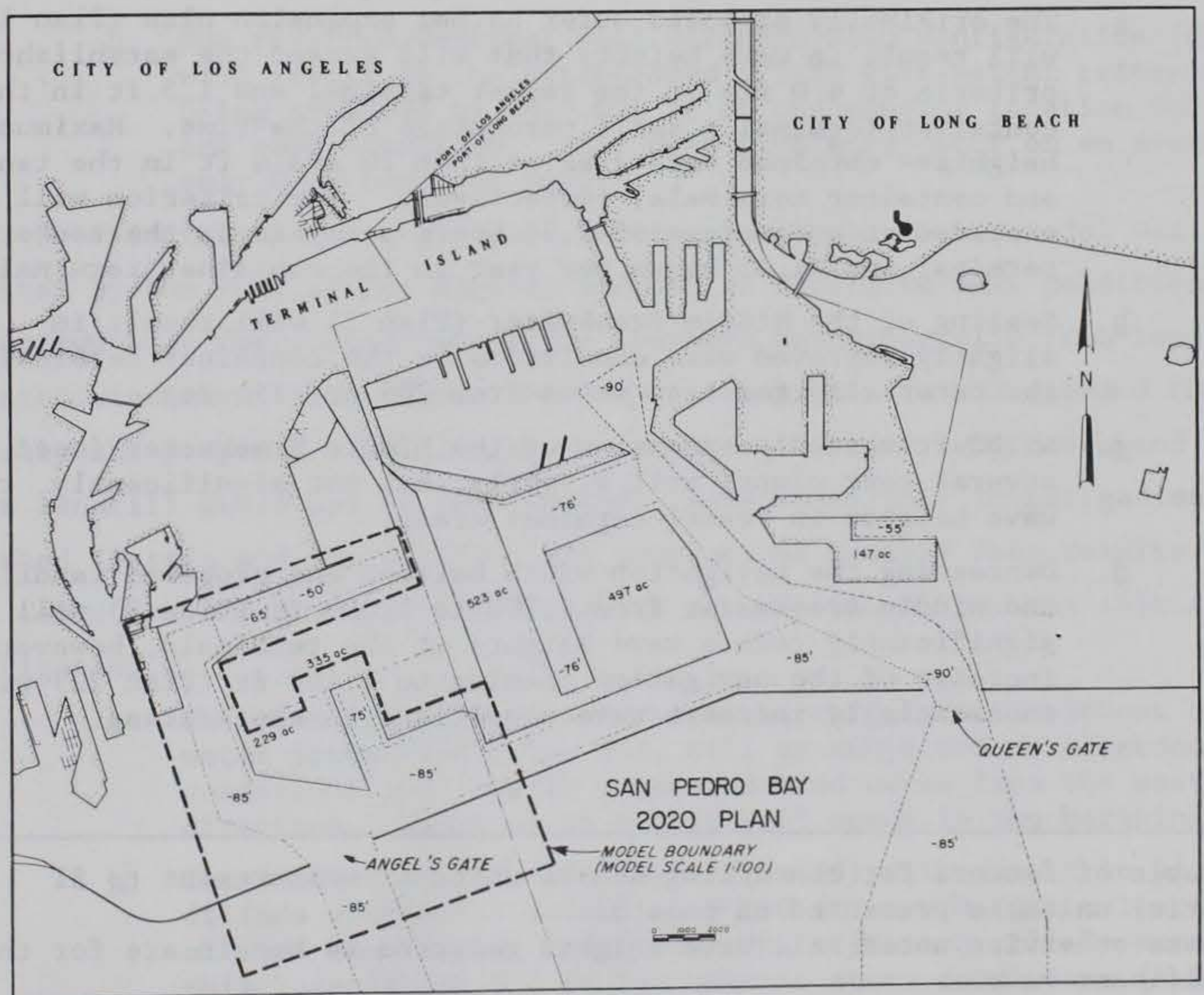

Figure 2. Approximate limits of model relative to harbor 
a. Determine short-period wave conditions in the entrance, in vessel maneuvering areas, and in berthing areas of the container ship and tanker terminals during periods of storm-wave activity for proposed harbor development located near Angel's Gate.

b. Develop remedial plans to improve wave conditions as found necessary.

c. Determine if design modification to the proposed plans could be made that would significantly reduce construction costs and still provide adequate protection.

\section{Previously Reported Model Tests and Conclusions}

4. The original purpose of the Los Angeles Outer Harbor model was to investigate short-period storm wave conditions for proposed harbor development located near the Angel's Gate entrance. Details of the investigation were published (Bottin and Tolliver 1989), and conclusions derived from study results are shown below. Plan numbers refer to those in the initial investigation.

a. The originally proposed outer harbor expansion plan (Plan 1) will result in wave heights that will exceed the established criteria of $6.0 \mathrm{ft*}$ in the tanker terminal and $1.5 \mathrm{ft}$ in the container terminal a small percentage of the time. Maximum wave heights** obtained were greater than 10 and $4 \mathrm{ft}$ in the tanker and container terminals, respectively. The criterion will be exceeded on an average of 7.35 hours per year in the tanker terminal and 21.45 hours per year in the container terminal.

b. Sealing of the Middle Breakwater (Plan 5) will result in slightly improved wave conditions in the container terminal of the outer slip for test waves from 209 and $154 \mathrm{deg}$.

c. A 200-ft westerly extension of the Middle Breakwater (used for several test plans) will slightly, but not significantly, reduce wave heights in vessel terminal areas.

d. Decreasing the navigation width between the proposed landfill and Middle Breakwater from 1,200 to 1,000 ft (Plan 8) will not significantly reduce wave heights at the terminals, however, an increase of the navigation opening to $1,400 \mathrm{ft}$ (Plan 22) will substantially increase wave conditions in these areas.

* A table of factors for converting Non-SI units of measurement to SI (metric) units is presented on page 3.

** Unless otherwise noted, all wave heights referred to herein are for the significant wave. 
e. The 1,800-ft-long San Pedro Breakwater spur in conjunction with a 200-ft westerly extension of the Middle Breakwater (Plan 14) will result in wave heights that exceed the established criterion in the container terminal and that meet the criterion in the tanker terminal areas. Maximum wave heights obtained in the container terminal were about $3 \mathrm{ft}$, but the criterion at this location will be exceeded on an average of only about 4.65 hours per year.

$\underline{f}$. The installation of vertical walls in the southern slip (Plan 19) will result in very rough and confused wave conditions in the container terminal due to wave reflections with wave heights up to $9 \mathrm{ft}$ at this location.

g. Reducing the southern slip basin width from 1,000 to $800 \mathrm{ft}$ (Plan 2) will result in wave heights that exceed the established criterion in the container and tanker terminals; however, wave heights were of less magnitude than the original Plan 1 expansion configuration and the criteria would be exceeded a smaller percentage of the time. Maximum wave heights were 8.2 and 2.6 $\mathrm{ft}$ in the tanker and container terminals, respectively. It is estimated the established $1.5 \mathrm{ft}$ criterion in the container terminal would be exceeded on an average of 3.45 hours per year, and the 6.0 -ft criterion in the tanker terminal exceeded about 4.2 hours per year.

h. The revetted/vertical wall northern slip configuration (Plan 24) will result in the established 1.5 -ft wave-height criterion being exceeded by only $0.2 \mathrm{ft}$ at one mooring location for only one wave condition. This condition will occur on an average of only 0.15 hour per year.

5. Additional testing of the Los Angeles Outer Harbor model was requested by the Port of Los Angeles and SPL to determine wave conditions and the optimum plan for protection of the southern container slip from locally generated wind waves from within the harbors complex. It was assumed that initially the proposed landfills in the adjacent Port of Long Beach and the Pactex landfill would not be constructed. Details of this investigation were published (Bottin and Acuff 1991), and conclusions derived from results of these tests are shown below. Plan numbers are continued from the initial investigation.

a. The southern container terminal berthing areas, without breakwater protection ( $\mathrm{P} 1$ an 25 ), will be subjected to hazardous wave conditions for locally generated wind waves from the easterly direction. Waves up to $5.0 \mathrm{ft}$ will occur in the berthing areas.

b. The 2,300-ft-long breakwater (Plan 26) will result in wave conditions within the established 2.0 - ft wave height criterion in all but one mooring location. The criterion will be exceeded at this location by $0.2 \mathrm{ft}$ for extreme storm conditions (4.2-sec, 4.9-ft incident waves) that will occur about 8.8 hours per year. 
c. The 2,100-ft-long breakwater ( $\mathrm{P} 1$ an 28 ) will result in waves substantially exceeding the criterion at one mooring area for extreme storm conditions. For less severe storm conditions (3.6-sec, 3.2-ft waves), however, the established $2.0-\mathrm{ft}$ wave height criterion would be met at all mooring locations.

d. The $800-\mathrm{ft}$-long breakwater ( $\mathrm{Plan} 32$ ) will result in wave heights within the established criterion at all but one mooring location for less severe storm conditions. The criterion will be exceeded by only $0.2 \mathrm{ft}$ at this location. For extreme wave conditions, however, wave heights will significantly exceed the criterion except in the northernmost berthing locations.

\section{Purpose of Current Investigation}

6. At the request of the Port of Los Angeles and SPL, the hydraulic model of Los Angeles Outer Harbor was again reactivated by CERC to determine wave conditions and the optimum plan for protection for various berthing areas during two construction phases of the proposed harbor expansion. Results of these tests are reported herein.

\section{Wave-Height Criteria}

7. Absolute criteria have not yet been developed for acceptable wave conditions that will ensure satisfactory mooring conditions in harbors during attack by waves. For this study, however, the Port of Los Angeles and SPL specified that for mooring conditions to be acceptable, maximum wave heights were not to exceed $6.0 \mathrm{ft}$ at tanker terminal locations, $2.5 \mathrm{ft}$ at a dry bulk terminal and $1.5 \mathrm{ft}$ at container terminal locations. 
PART II: MODEL

\section{Design of Model}

8. The Los Angeles Outer Harbor Model (Figure 3) was constructed to an undistorted linear scale of $1: 100$, model to prototype. Scale selection was based on such factors as:

a. Depth of water required in the model to prevent excessive bottom friction.

b. Absolute size of model waves.

c. Available shelter dimensions and area required for model construction.

d. Efficiency of model operation.

e. Available wave-generating and wave-measuring equipment.

f. Model construction costs.

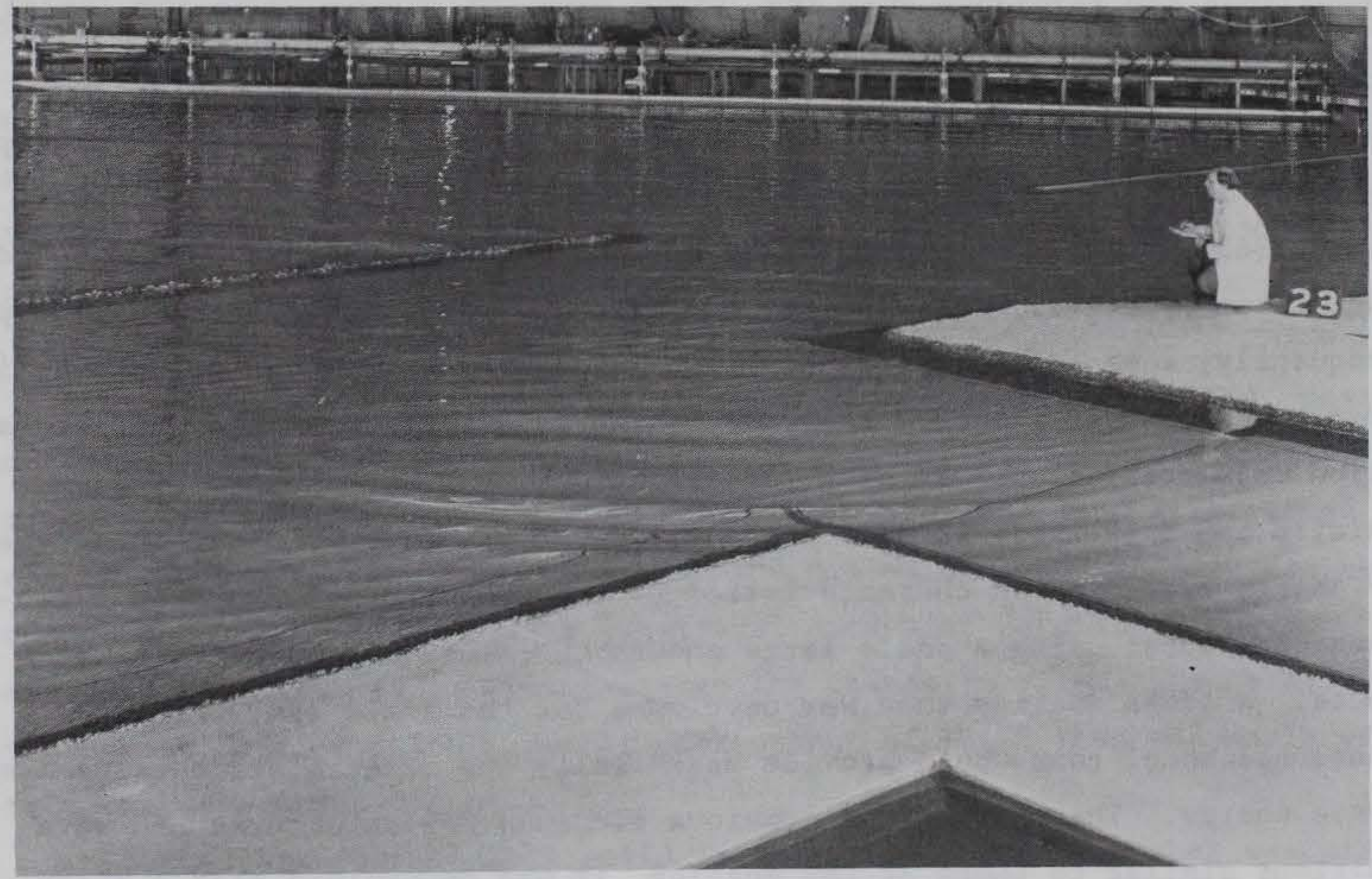

Figure 3. General view of model

A geometrically undistorted model was necessary to ensure accurate reproduction of short-period wave patterns including the effects of wave refraction, diffraction, and reflection. Following selection of the linear scale, the model 
was designed and operated in accordance with Froude's model law (Stevens et al. 1942). The scale relations used for design and operation of the model were as follows :

\begin{tabular}{cc} 
Characteristic & Dimension* \\
\cline { 2 - 2 } Length & $\mathrm{L}$ \\
Area & $\mathrm{L}^{2}$ \\
Volume & $\mathrm{L}^{3}$ \\
Time & $\mathrm{T}$ \\
Velocity & $\mathrm{L} / \mathrm{T}$
\end{tabular}

Model-Prototype Scale Relations

$\mathrm{L}_{\mathbf{r}}=1: 100$

$A_{r}=L_{r}^{2}=10,000$

$\forall_{x}=L_{r}^{3}=100,000$

$\mathrm{T}_{\mathrm{r}}=\mathrm{L}_{\mathrm{r}}{ }^{\frac{1}{2}}=1: 10$

$V_{r}=L_{r}^{\frac{1}{2}}=1: 10$

* Dimensions are in terms of length (L) and time (T).

9. The existing breakwaters and proposed revetments at Los Angeles Harbor are rubble-mound structures. Experience and experimental research have shown that considerable wave energy passes through the interstices of this type structure; thus, the transmission and absorption of wave energy became a matter of concern in design of the 1:100-scale model. In small-scale hydraulic models, rubble-mound structures reflect relatively more and absorb or dissipate relatively less wave energy than geometrically similar prototype structures (Le Méhauté 1965). Also, the transmission of wave energy through a rubble-mound structure is relatively less for the small-scale model than for the prototype. Consequently, some adjustment in small-scale model rubble-mound structures is needed to ensure satisfactory reproduction of wave-reflection and wave-transmission characteristics. In past investigations (Dai and Jackson 1966, Brasfeild and Ball 1967) at WES, this adjustment was made by determining the wave-energy transmission characteristics of the proposed structure in a twodimensional model using a scale large enough to ensure negligible scale effects. A cross section then was developed for the small-scale, threedimensional model that would provide essentially the same relative transmission of wave energy. Therefore, from previous findings for structures and wave conditions similar to those at Los Angeles, it was determined that a close approximation of the correct wave-energy transmission characteristics could be obtained by increasing the size of the rock used in the 1:100-scale model to approximately two times that required for geometric similarity. Accordingly, in constructing the rubble-mound structures in the Los Angeles model, the rock 
sizes were computed linearly by scale, then multiplied by 2 to determine the actual sizes to be used in the model.

\section{Model and Appurtenances}

10. The model, which was molded in cement mortar, reproduced the proposed harbor expansion phases, Angel's Gate entrance, 2,800 and 5,100 ft of the San Pedro and Middle Breakwaters, respectively, and underwater contours in San Pedro Bay to an offshore depth of $60 \mathrm{ft}$ with a sloping transition to the wave generator pit elevation* of $-100 \mathrm{ft}$. The total area reproduced in the model was approximately $27,500 \mathrm{sq} \mathrm{ft}$, representing about 10 square miles in the prototype. A model layout is shown in Figure 4. Vertical control for model construction was based on mean lower low water (m1lw). Horizontal control was referenced to a local prototype grid system.

11. Prototype wave conditions were reproduced in the model by an 80 -ft-long, unidirectional spectral wave generator with a trapezoidal-shaped, vertical motion plunger. For some tests, the wave generator was shortened to $50 \mathrm{ft}$ in length. The electrohydraulic wave generator utilized a hydraulic power supply, and the vertical motion of its plunger was controlled by a computer-generated command signal. The controlled movement of the plunger caused water displacements which reproduced the required test waves. The wave generator was mounted on retractable casters which enabled it to be positioned to generate waves from the required directions.

12. An automated date acquisition and control system (ADACS), designed and constructed at WES was used to generate and transmit control signals, monitor wave generator feedback, and secure and analyze wave data at selected locations in the model. Basically, through the use of a MICROVAX computer, ADACS recorded onto magnetic disks the electrical output of parallel-wire, resistance-type wave gages that measured the change in water-surface elevation with respect to time. The magnetic disk output of ADACS then was analyzed to obtain the wave data.

13. A 2-ft (horizontal) solid layer of fiber wave absorber was placed around the inside perimeter of the model to dampen wave energy that might otherwise be reflected from the model walls. In addition, guide vanes were

* All elevations (el) cited herein are in feet referred to as mean lower low water (mllw) unless otherwise noted. 


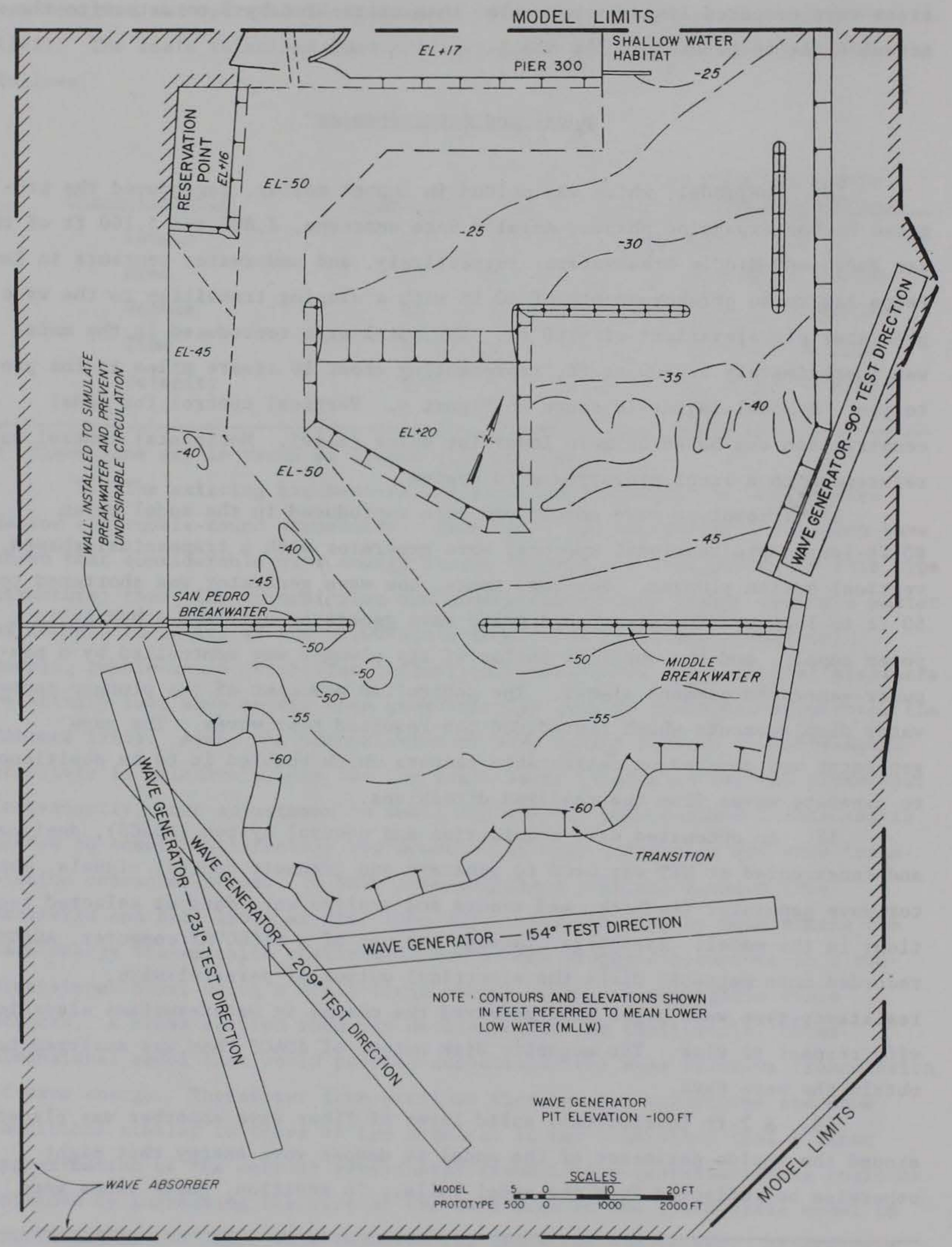

Figure 4. Model layout 
placed along the wave generator sides in the flat pit area to ensure proper formation of the wave train incident to the model contours. 


\section{Selection of Test Conditions}

\section{Still-water level}

14. Still-water levels (swl's) for harbor wave action models are selected so that the various wave-induced phenomena that are dependent on water depths are accurately reproduced in the model. These phenomena include the refraction of waves in the project area, the overtopping of harbor structures by the waves, the refection of wave energy from various structures, and the transmission of wave energy through porous structures.

15. In most cases, it is desirable to select a model swl that closely approximates the higher water stages which normally occur in the prototype for the following reasons:

a. The maximum amount of wave energy reaching a coastal area normally occurs during the higher water phase of the local tidal cycle.

b. Most storms moving onshore are characteristically accompanied by a higher water level due to wind tide and shoreward mass transport.

c. The selection of a high swl helps minimize model scale effects due to viscous bottom friction.

d. When a high swl is selected, a model investigation tends to yield more conservative results.

16. An swl of $+5.5 \mathrm{ft}$ was selected by the Port of Los Angeles and SPL for use during model testing. This value $(+5.5)$ represents mean higher high water in Los Angeles Outer Harbor.

Factors influencing selection

of test wave characteristics

17. In planning the testing program for a model investigation of harbor wave-action problems, it is necessary to select dimensions and directions for the test waves that will allow a realistic test of proposed improvement plans and an accurate evaluation of the elements of the various proposals. Surfacewind waves are generated primarily by the interactions between tangential stresses of wind flowing over water, resonance between the water surface and atmospheric turbulence, and interactions between individual wave components. The height and period of the maximum wave that can be generated by a given storm depend on the wind speed, the length of time that wind of a given speed continues to blow, and the distance over the water (fetch) which the wind 
blows. Selection of test wave conditions entails evaluation of such factors as :

a. The fetch and decay distances (the latter being the distance over which waves travel after leaving the generating area) for various directions from which waves can attack the problem area.

b. The frequency of occurrence and duration of storm winds from the different directions.

c. The alignment, size, and relative geographic position of the navigation entrance to the harbor.

d. The alignments, lengths, and locations of the various reflecting surfaces inside the harbor.

e. The refraction of waves caused by differentials in depth in the area seaward of the harbor, which may create either a concentration or a diffusion of wave energy at the harbor site.

Wave refraction

18. When wind waves move into water of gradually decreasing depth, transformations take place in all wave characteristics except wave period (to the first order of approximation). The most important transformations with respect to the selection of test wave characteristics are the changes in wave height and direction of travel due to the phenomenon referred to as wave refraction. The change in wave height and direction may be determined by conducting a wave-refraction analysis. The shoaling coefficient, a function of wave length and water depth, can be obtained from the Shore Protection Manual (USAEWES 1984). When the refraction coefficient is determined, it is multiplied by the shoaling coefficient and gives a conversion factor for transfer of deepwater wave heights to shallow-water values.

19. Refraction and shoaling coefficients were obtained at Los Angeles Harbor for various wave periods from several deepwater wave directions, and are presented in Table 1. Refraction coefficients were obtained from a previous study involving transmission and overtopping of the harbor structures (Hales 1976), and represent an average of the values in the vicinity just outside Angel's Gate (approximately the location of the wave generator in the model). Shoaling coefficients were computed for a 105.5 -ft water depth (100-ft wave generator pit elevation with 5.5 -ft tide conditions superimposed) corresponding to the depth reproduced at the model wave generator. The wave height adjustment factor can be applied to any deepwater wave height to obtain the corresponding shallow-water value. Refracted wave directions were secured by analyzing refraction diagrams from Wilson (1968). Based on these results, 
three test directions, as shown, representing seven deepwater directions were selected for use during model testing:

Deepwater Directions Represented Selected Shallow-Water Azimuth, deg Test Direction, deg

West, 270

West-Southwest, 247.5

Southwest, 225

South-Southwest, 202.5

South, 180

South-Southeast, 157.5

Southeast, 135

154

The shallow-water wave directions selected represented the average of the refracted wave directions for the deepwater directions noted.

20. A wave refraction analysis was not conducted for easterly waves due to the limited fetch from which waves can be generated. The magnitude and direction of winds were considered to be the governing factors, and waves from the east were assumed to be locally generated. The critical direction of wave approach was determined to be from $90 \mathrm{deg}$ (due east) for these tests.

Prototype wave data and selection of test waves

21. Measured short-period, prototype wave data on which a comprehensive statistical analysis of wave conditions could be based were unavailable for the Los Angeles Harbor area. However, statistical deepwater wave hindcast data representative of this area were obtained from the CERC Wave Information Studies (WIS) by Corson et al. (1987). Deepwater data are summarized in Table 2. These data are representative of conditions west of the islands off the California coast. As deepwater waves approach Los Angeles Harbor from west counterclockwise through south, wave propagation is inhibited due to the offshore islands which partially shelter the harbor. Sheltering coefficients obtained at an adjacent site during another study (Hales 1987) were applied to these deepwater wave characteristics and resulted in deepwater wave conditions landward of the islands (Table 3 ). The data then were converted to shallowwater values by application of refraction and shoaling coefficients and are shown in Table 4. Characteristics of test waves used in the model (selected from Table 4) are shown in the following tabulation: 


\begin{tabular}{cl}
\hline Period, sec & Height, ft \\
5 & 4,10 \\
7 & $4,10,14$ \\
9 & $4,10,14$ \\
11 & $4,8,12$ \\
13 & $4,8,12$ \\
15 & 6,12 \\
17 & 4,8 \\
7 & \\
9 & 8,12 \\
11 & 8,16 \\
15 & $6,10,16$ \\
& 8 \\
5 & \\
7 & 10 \\
11 & 8,12 \\
15 & 10 \\
& 1022
\end{tabular}

Unidirectional wave spectra (based on JONSWAP parameters) for the test waves listed above were reproduced for tests throughout the investigation.

22. For locally generated wind waves, conditions representative of this area were obtained by the application of hindcasting techniques from the Shore Protection Manual (USAEWES 1984) to wind data acquired at Long Beach Harbor during the period 1974-1981. Test waves selected from these data are shown below:

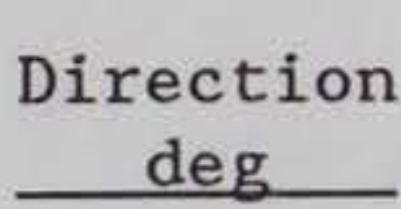

90

90



3.6

4.2
Wave Height $\mathrm{ft}$

3.2

4.9

Based on the hindcasting techniques, it was estimated that the 3.6 -sec waves would occur approximately 43.8 hours per year, and the $4.2-\mathrm{sec}$ wave conditions about 8.8 hours per year. Unidirectional wave spectra (based on TMA parameters) were produced to represent these test waves.

\section{Analysis of Model Data}

23. Relative merits of the various plans tested were evaluated by a comparison of wave heights at selected locations in the model, visual observations, and wave pattern photographs. In the wave-height analysis, the average height of the highest one third of the waves $\left(H_{s}\right)$ recorded at each gage location was computed. All wave heights then were adjusted to compensate for 
excessive wave-height attenuation due to viscous model bottom friction, by application of Keulegan's equation (Keulegan 1950).* From this equation, reduction of wave heights in the model (relative to the prototype) can be calculated as a function of water depth, width of wave front, wave period, water viscosity, and distance of wave travel.

* G. H. Keulegan, 1950. "The Gradual Damping of a Progressive Oscillatory Wave with Distance in a Prismatic Rectangular Channel," unpublished data, National Bureau of Standards, Washington, DC, prepared at request of Director, WES, Vicksburg, MS, by letter of 2 May 1950. 


\section{Tests}

\section{Test Plans}

22. Wave height tests were conducted for two phases of construction for the Los Angeles Outer Harbor expansion plan. Variations to the first construction phase consisted of shortening the proposed breakwaters inside the harbors' complex. Only the original second construction phase was tested. Wave pattern photographs were obtained for representative test waves for each phase of construction. Brief descriptions of the test plans are presented in the following subparagraphs; dimensional details are presented in Plates 1-3.

a. Plan 1 (Plate 1) consisted of the first phase of construction for the Los Angeles Outer Harbor expansion. It included a 50-ft-deep, approximately 1,000-ft-wide dredged channel extending northerly from the main channel along Reservation Point, and then easterly adjacent to Pier 300. A landfill was constructed with the dredged material north of the Angel's Gate entrance to provide wave protection to the inner berthing areas formed adjacent to Pier 300 . The construction phase also included a 2,600-ft-long breakwater extending easterly from the northern portion of the landfill and a 2,500-ft-long detached breakwater to the east aligned on the Los Angeles-Long Beach Harbors boundary line.

b. Plan 2 (Plate 1) included the elements of Plan 1 but $300 \mathrm{ft}$ of the southern end of the detached breakwater was removed which resulted in 2,200-ft-long structure.

c. Plan 3 (Plate 1) entailed the elements of Plan 1 but $600 \mathrm{ft}$ of the southern end of the detached breakwater was removed which resulted in a $1,900-\mathrm{ft}$-long structure.

d. Plan 4 (Plate 1) involved the elements of Plan 1 but $900 \mathrm{ft}$ of the southern end of the detached breakwater was removed which resulted in a $1,600-\mathrm{ft}$-long structure.

e. Plan 5 (Plate 1) included the elements of Plan 1 but 1,200 ft of the southern end of the detached breakwater was removed which resulted in a $1,300-\mathrm{ft}-1$ ong structure.

f. Plan 6 (Plate 2) entailed the Plan 1 construction phase and the 1,300-ft-long detached structure of Plan 5, but $300 \mathrm{ft}$ of the eastern end of the attached breakwater was removed which resulted in a $2,300-\mathrm{ft}$-long structure.

g. Plan 7 ( $P$ late 2) included the Plan 1 construction phase and the 1,300-ft-long detached structure of Plan 5, but $600 \mathrm{ft}$ of the eastern end of the attached breakwater was removed which resulted in a $2,000-\mathrm{ft}$-long structure. 
h. Plan 8 (Plate 2) involved the Plan 1 construction phase and the $1,300-\mathrm{ft}$-long detached structure of Plan 5, but $900 \mathrm{ft}$ of the eastern end of the attached breakwater was removed which resulted in a $1,700-\mathrm{ft}$-long structure.

i. Plan 9 (Plate 2) entailed the Plan 1 construction phase and the 1,300-ft-long detached structure of Plan 5, but 1,200 ft of the eastern end of the attached breakwater was removed which resulted in a $1,400-\mathrm{ft}-1$ ong structure.

i. Plan 10 (Plate 2) entailed the Plan 1 construction phase and the 1,300-ft-long detached structure of Plan 5, but 1,500 ft of the eastern end of the attached breakwater was removed which resulted in a $1,100-\mathrm{ft}$-long structure.

k. Plan 11 (Plate 2) included the Plan 1 construction phase with $1,500 \mathrm{ft}$ of the eastern end of the attached structure removed and $1,500 \mathrm{ft}$ of the southern end of the detached structure removed. This resulted in an 1,100-ft-long attached breakwater and a 1,000-ft-long detached breakwater.

1. Plan 12 (Plate 2) involved the Plan 1 construction phase with $1,500 \mathrm{ft}$ of the eastern end of the attached breakwater removed and $1,800 \mathrm{ft}$ of the southern end of the detached breakwater removed. This resulted in an 1,100-ft-long attached structure and $700-\mathrm{ft}-1$ ong detached structure.

m. Plan 13 (Plate 2) entailed the Plan 1 construction phase with $1,800 \mathrm{ft}$ of the eastern end of the attached breakwater removed and $1,500 \mathrm{ft}$ of the southern end of the detached breakwater removed. This resulted in an $800-\mathrm{ft}$-long attached structure and a 1,000-ft-long detached structure.

n. Plan 14 (Plate 3) involved the second phase of construction for the Los Angeles Outer Harbor expansion. It consisted of additional dredging and additional landfill area. A channel was dredged to a depth of $72 \mathrm{ft}$ that extended from the $72 \mathrm{ft}$ contour in San Pedro Bay through Angel's Gate entrance northerly adjacent to Reservation Point. An area also was dredged to 75 ft east of the proposed landfill. Using the dredged material, additional landfill was constructed east of and north of the first phased landfill.

Wave height tests and wave patterns

25. Wave height tests for the various test plans were obtained for test waves from one or more of the directions listed in paragraphs 21 and 22 and the wave gage locations shown in Plates 1-3. The $80-\mathrm{ft}$-long wave machine was reduced to $50 \mathrm{ft}$ in length for reproduction of the locally generated waves. Wave pattern photographs were secured for representative test plans to provide documentation of test results. 


\section{Test Results}

26. In evaluating test results, the relative merits of the various plans were based on an analysis of measured wave heights in the proposed mooring areas. Model wave heights (significant wave height or $\mathrm{H}_{1 / 3}$ ) were tabulated to show measured values at selected locations.

\section{Test plans}

27. Results of wave height tests conducted for Plans 1-13 are presented in Table 5 for locally generated wave conditions from $90 \mathrm{deg}$. Maximum wave heights were $1.3,1.6,2.0,2.1,1.9,1.8,2.2,2.4,2.4,2.0,2.0,2.0$, and $2.2 \mathrm{ft}$ at the proposed dry bulk terminal (gage 9) and $0.5,0.6,0.6,0.8,1.3$, $1.2,1.4,1.3,1.2,1.3,1.5,1.9$ and $1.7 \mathrm{ft}$ at the proposed container terminal (gage 10) for Plans 1-13, respectively. Typical wave patterns obtained for Plans 1 and 11 at the inner berthing locations adjacent to Pier 300 are shown in Photos 1-4.

28. Wave height test results obtained for the optimum first construction phase alternative (Plan 11) are presented in Table 6 for incident waves from 231, 209, and $154 \mathrm{deg}$. Maximum wave heights obtained at the tanker terminal (gage 6) were $3.9 \mathrm{ft}$ for $15 \mathrm{sec}, 10 \mathrm{ft}$ test wave from $154 \mathrm{deg}$. At the dry bulk terminal (gage 9) maximum wave heights were $1.2 \mathrm{ft}$ for $11-\mathrm{sec}$, 16-ft test waves from $209 \mathrm{deg}$, and maximum wave heights at the container terminal (gage 10) were $1.5 \mathrm{ft}$ for $15-\mathrm{sec}, 12 \mathrm{ft}$ test waves from $231 \mathrm{deg}$, and $11-\mathrm{sec}$, $16 \mathrm{ft}$ and $15 \mathrm{-sec}, 8 \mathrm{ft}$ test waves from $209 \mathrm{deg}$. Representative wave patterns secured for Plan 11 for test waves from 231, 209, and $154 \mathrm{deg}$ are shown in Photos 5-10.

29. Results of wave height tests for the second construction phase alternative (Plan 14) are presented in Table 7 for incident waves from 231, 209, and $154 \mathrm{deg}$. Maximum wave heights were $2.8 \mathrm{ft}$ at the tanker terminal (gage 2) for $9-\mathrm{sec}, 16-\mathrm{ft}$ and $11 \mathrm{sec}, 16-\mathrm{ft}$ test waves from $209 \mathrm{deg} ; 1.0 \mathrm{ft}$ at the dry bulk terminal (gage 9) for 11-sec, 10-ft test waves from 154 deg; and $1.0 \mathrm{ft}$ at the container terminal (gage 10) for $11-\mathrm{sec}, 16-\mathrm{ft}$ test waves from 209 deg. Typical wave patterns obtained for Plan 14 are shown in Photos 11-16 for test waves from 231, 209, and $154 \mathrm{deg}$. 


\section{Discussion of test results}

30. Results of wave height tests for the first phase of construction (Plan 1) indicated that maximum wave heights of 1.3 and $0.5 \mathrm{ft}$ would occur at the dry bulk terminal (gage 9) and the container terminal (gage 10), respectively, for locally generated waves from $90 \mathrm{deg}$. This was well within the established wave height criteria of 2.5 and $1.5 \mathrm{ft}$, respectively. Test results indicated that $1,500 \mathrm{ft}$ could be removed from the eastern end of the breakwater attached to the landfill and $1,500 \mathrm{ft}$ could be removed from the southern end of the detached breakwater (Plan 11), and the criteria would still be met. Plan 11 was considered the optimum plan for the first construction phase and was selected for further testing.

31. Comprehensive wave height test results for the optimum breakwater arrangement (Plan 11) for the first phase of construction for test waves from 231, 209, and $154 \mathrm{deg}$ indicated that the established criteria would be met for waves from all directions. Maximum wave heights at the tanker terminals were greater than $2.0 \mathrm{ft}$ below the $6.0 \mathrm{ft}$ wave height criterion, maximum wave heights at the dry bulk terminal were greater than $1.0 \mathrm{ft}$ below the $2.5 \mathrm{ft}$ wave height criterion, and maximum wave heights at the container terminal were $1.5 \mathrm{ft}$ (the established criterion). Construction of the Plan 11 alternative of the first construction phase should provide adequate wave protection to the berthing areas during periods of storm wave attack for both deepwater waves and locally generated wave conditions.

32. Results of wave height tests for the second phase of construction (P1an 14) for test waves from 231, 209, and 154 deg indicated that the established criterion would be met for waves from all directions. Maximum wave heights at the tanker terminals were greater than $3.0 \mathrm{ft}$ below the $6.0 \mathrm{ft}$ wave height criterion, maximum wave heights at the dry bulk terminal were $1.5 \mathrm{ft}$ below the $2.5-\mathrm{ft}$ wave height criterion, and maximum wave heights at the container terminal were $0.5 \mathrm{ft}$ below the $1.5 \mathrm{ft}$ wave height criterion. Construction of the second construction phase (Plan 14) should provide adequate wave protection to the berthing areas during periods of storm wave attack for deepwater wave conditions. Due to the landfill east of the berthing areas, locally generated wind waves within the harbors complex will not be a problem for this construction phase. 


\section{PART V: CONCLUSIONS}

33. Based on the results of the hydraulic model investigation reported herein, it is concluded that:

a. The originally proposed first phase of construction (Plan 1) tested would result in wave heights well within the established criteria of $2.5 \mathrm{ft}$ in the dry bulk terminal and $1.5 \mathrm{ft}$ in the container terminal for locally generated waves within the harbors complex.

b. A total of 3,000 ft of breakwater length can be removed from the first phase of construction (Plan 11) and the established criteria will still be met for locally generated wind waves.

c. The Plan 11 alternative of the first phase of construction $(3,000 \mathrm{ft}$ of breakwater removed) will provide adequate wave protection to the berthing areas during periods of storm wave attack for deep water wave conditions.

d. The second phase of construction (Plan 14) will provide adequate wave protection to the berthing areas during periods of storm wave attack from deep water. 


\section{REFERENCES}

Bottin, R. R., Jr. 1988. "Case Histories of Corps Breakwater and Jetty Structures; Report 1, South Pacific Division," Technical Report REMR-C0-3, Repair, Evaluation, Maintenance, and Rehabilitation Research Program, US Army Engineer Waterways Experiment Station, CE, Vicksburg, MS.

Bottin, R. R., Jr., and Tolliver, L. R. 1989. "Wave Conditions for Proposed Harbor Development in Los Angeles Outer Harbor, Los Angeles, California; Coastal Model Investigation," Technical Report CERC-89-13, US Army Engineer Waterways Experiment Station, Vicksburg, MS .

Bottin, R. R., Jr., and Acuff, H. F. 1991. "Wave Conditions for Proposed Harbor Development in Los Angeles Outer Harbor, Los Angeles, California, Supplemental Tests; Coastal Model Investigation," Technical Report CERC-91-4, US Army Engineer Waterways Experiment Station, Vicksburg, MS.

Brasfeild, C. W., and Ball, J. W. 1967. "Expansion of Santa Barbara Harbor, California; Hydraulic Model Investigation," Technical Report No. 2-805, US Army Engineer Waterways Experiment Station, CE, Vicksburg, MS.

Corson, W. D. et al. 1987. "Pacific Coast Hindcast Phase II Wave Information," WIS Report 16, US Army Engineer Waterways Experiment Station, Vicksburg, MS .

Dai, Y. B., and Jackson, R. A. 1966. "Design for Rubble-Mound Breakwaters, Dana Point Harbor, California; Hydraulic Model Investigation," Technical Report No. 2-725, US Army Engineer Waterways Experiment Station, Vicksburg, MS.

Hales, L. Z. 1976. "Transmission of Wave Energy Through and Overtopping of the Long Beach, California, Breakwater," Miscellaneous Paper H-76-10, US Army Engineer Waterways Experiment Station, Vicksburg, MS.

Hales L. Z. 1987. "Water Wave Effects at Redondo Beach King Harbor, California," Miscellaneous Paper CERC-87-2, US Army Engineer Waterways Experiment Station, Vicksburg, MS .

Le Méhauté, B. 1965. "Wave Absorbers in Harbors," Contract Report No. 2-122, US Army Engineer Waterways Experiment Station, CE, Vicksburg, MS, prepared by National Engineering Science Company, Pasadena, CA, under Contract No. DA-22-079-CIVENG-64-81.

Stevens, J. C. et al. 1942. "Hydraulic Models," Manuals of Engineering Practice No. 25, American Society of Civil Engineers, New York, NY.

US Army Engineer Waterways Experiment Station. 1984. Shore Protection Manual. 4 th ed., 2 Vols, US Army Engineer Waterways Experiment Station, Coastal Engineering Research Center, US Government Printing Office, Washington, DC.

Wilson, B. W. et al. 1968. "Wave and Surge Action Study for Los Angeles-Long Beach Harbors," Final Report No. 1, US Army Engineer District, Los Angeles, Los Angeles, CA. 
Table 1

Summary of Refraction and Shoaling Analysis at

Angel's Gate, Los Angeles Harbor, California

\begin{tabular}{|c|c|c|c|c|}
\hline $\begin{array}{c}\text { Deepwater } \\
\text { Direction } \\
\text { deg } \\
\end{array}$ & $\begin{array}{c}\text { Wave } \\
\text { Period } \\
\text { sec } \\
\end{array}$ & $\begin{array}{l}\text { Refraction } \\
\text { Coefficient }\end{array}$ & $\begin{array}{c}\text { Shoaling* } \\
\text { Coefficient }\end{array}$ & $\begin{array}{c}\text { Wave-Height } \\
\text { Adjustment } \\
\text { Factor }\end{array}$ \\
\hline W, 270.0 & $\begin{array}{r}9 \\
11 \\
13 \\
15 \\
17 \\
19\end{array}$ & $\begin{array}{l}0.45 \\
0.45 \\
0.45 \\
0.46 \\
0.46 \\
0.47\end{array}$ & $\begin{array}{l}0.937 \\
0.913 \\
0.920 \\
0.941 \\
0.969 \\
1.001\end{array}$ & $\begin{array}{l}0.422 \\
0.411 \\
0.414 \\
0.433 \\
0.446 \\
0.470\end{array}$ \\
\hline WSW, 247.5 & $\begin{array}{r}5 \\
7 \\
9 \\
11 \\
13 \\
15 \\
17 \\
19\end{array}$ & $\begin{array}{l}1.00 \\
0.72 \\
0.74 \\
0.70 \\
0.69 \\
0.69 \\
0.67 \\
0.67\end{array}$ & $\begin{array}{l}1.000 \\
0.980 \\
0.937 \\
0.913 \\
0.920 \\
0.941 \\
0.969 \\
1.001\end{array}$ & $\begin{array}{l}1.000 \\
0.706 \\
0.693 \\
0.639 \\
0.635 \\
0.649 \\
0.649 \\
0.671\end{array}$ \\
\hline SW, 225.0 & $\begin{array}{r}5 \\
7 \\
9 \\
11 \\
13 \\
15 \\
17 \\
19\end{array}$ & $\begin{array}{l}1.00 \\
0.94 \\
0.94 \\
0.91 \\
0.79 \\
0.70 \\
0.60 \\
0.59\end{array}$ & $\begin{array}{l}1.000 \\
0.980 \\
0.937 \\
0.913 \\
0.920 \\
0.941 \\
0.969 \\
1.001\end{array}$ & $\begin{array}{l}1.000 \\
0.921 \\
0.881 \\
0.831 \\
0.727 \\
0.659 \\
0.581 \\
0.591\end{array}$ \\
\hline SSW, 202.5 & $\begin{array}{r}5 \\
7 \\
9 \\
11 \\
13 \\
15 \\
17 \\
19\end{array}$ & $\begin{array}{l}1.00 \\
0.99 \\
1.10 \\
1.13 \\
1.03 \\
0.93 \\
0.85 \\
0.78\end{array}$ & $\begin{array}{l}1.000 \\
0.980 \\
0.937 \\
0.913 \\
0.920 \\
0.941 \\
0.969 \\
1.001\end{array}$ & $\begin{array}{l}1.000 \\
0.970 \\
1.031 \\
1.032 \\
0.948 \\
0.875 \\
0.824 \\
0.781\end{array}$ \\
\hline
\end{tabular}

(Continued)

* At $105.5-\mathrm{ft}$ depth (100-ft pit elevation with 5.5 -ft tide superimposed). 
Table 1. (Concluded)

\begin{tabular}{lcccc}
\hline $\begin{array}{c}\text { Deepwater } \\
\text { Direction } \\
\text { deg }\end{array}$ & $\begin{array}{c}\text { Wave } \\
\text { Period } \\
\text { sec }\end{array}$ & $\begin{array}{c}\text { Refraction } \\
\text { Coefficient }\end{array}$ & $\begin{array}{c}\text { Shoaling* } \\
\text { Coefficient }\end{array}$ & $\begin{array}{c}\text { Wave-height } \\
\text { Adjustment } \\
\text { Factor }\end{array}$ \\
\cline { 2 - 3 } S, 180.0 & 5 & 1.00 & 1.000 & 1.000 \\
& 7 & 0.97 & 0.980 & 0.951 \\
& 9 & 1.01 & 0.937 & 0.946 \\
& 11 & 0.83 & 0.913 & 0.758 \\
SSE, 157.5 & 13 & 0.75 & 0.920 & 1.054 \\
& 15 & 1.12 & 0.941 & 1.337 \\
SE, 135.0 & 19 & 1.38 & 1.001 & 1.291 \\
& 5 & 1.00 & 1.000 & 1.000 \\
& 5 & 1.18 & 0.980 & 1.000
\end{tabular}


Table 2

Estimated Magnitude of Unshe1tered Deepwater Waves (Sea and Swe11) Approaching Los Angeles-Long Beach Harbors from the Directions Indicated

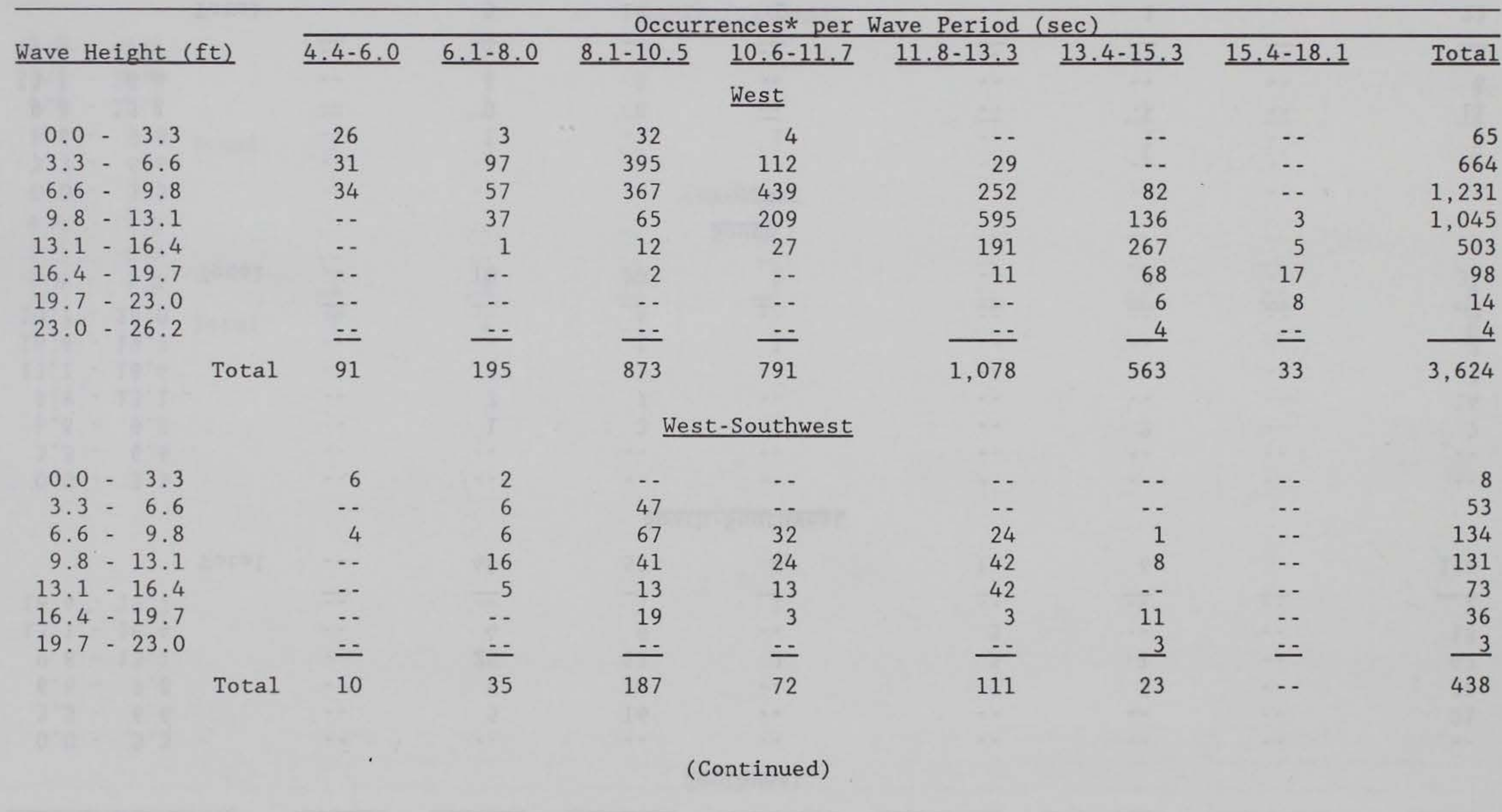

* Occurrences compiled for period 1956-1975. Each occurrence represents a 3-hr duration. 
Table 2. (Continued)

\begin{tabular}{|c|c|c|c|c|c|c|c|c|c|}
\hline \multirow{2}{*}{\multicolumn{2}{|c|}{ Wave Height, (ft) }} & \multicolumn{8}{|c|}{ Occurrences per Wave Period (sec) } \\
\hline & & $4.4-6.0$ & $6.1-8.0$ & $8.1-10.5$ & $10.6-11.7$ & $11.8-13.3$ & $13.4-15.3$ & $15.4-18.1$ & Total \\
\hline \multicolumn{10}{|c|}{ Southwest } \\
\hline $0.0-3.3$ & & .. & .- & .. & .. & .. & .. & .. & .- \\
\hline $3.3-6.6$ & & .- & 5 & 16 & -- & -. & -. & .- & 21 \\
\hline $6.6-9.8$ & & -. & 6 & 14 & -. & 1 & 5 & -. & 26 \\
\hline $9.8-13.1$ & & .. & 25 & 13 & 3 & 5 & 1 & -. & 47 \\
\hline $13.1-16.4$ & & -. & 4 & 9 & -. & 5 & -. & -. & 18 \\
\hline $16.4-19.7$ & & $=$ & - & 1 & 1 & $=$ & $=$ & - & 2 \\
\hline & Total & -. & 40 & 53 & 4 & 11 & 6 & & 114 \\
\hline \multicolumn{10}{|c|}{ South-Southwest } \\
\hline $0.0-3.3$ & & .- & .. & .. & -. & -. & -. & .. & .. \\
\hline $3.3-6.6$ & & .. & .. & -. & -. & -. & -. & .. & -. \\
\hline $6.6-9.8$ & & -. & 1 & 3 & 1 & -. & 2 & -. & 7 \\
\hline $9.8-13.1$ & & -- & 7 & 7 & - & -. & -. & -. & 14 \\
\hline $13.1-16.4$ & & -. & 2 & 5 & -. & -. & -. & .. & 7 \\
\hline $16.4-19.7$ & & -. & -. & 1 & 1 & -. & -- & -. & 2 \\
\hline $19.7-23.0$ & & $=$ & ․ & 4 & $=$ & $=$ & - & ㅡ & 4 \\
\hline & Total & -. & 10 & 20 & 2 & -. & 2 & -. & 34 \\
\hline \multicolumn{10}{|c|}{ South } \\
\hline $0.0-3.3$ & & .. & .- & -. & -. & -. & -. & .. & -. \\
\hline $3.3-6.6$ & & .- & -. & .. & -. & -. & .. & .- & -. \\
\hline $6.6-9.8$ & & -. & 1 & -- & 1 & -. & 1 & -- & 3 \\
\hline $9.8-13.1$ & & -- & 3 & 8 & -. & -. & .. & -. & 11 \\
\hline $13.1-16.4$ & & -. & 1 & 5 & -. & -. & -. & .- & 6 \\
\hline $16.4-19.7$ & & 二 & - & 1 & $=$ & 二 & 二 & = & 1 \\
\hline & Total & -. & 5 & 14 & 1 & -. & 1 & -. & 21 \\
\hline \multicolumn{10}{|c|}{ (Continued) } \\
\hline
\end{tabular}

(Sheet 2 of 3 ) 
Table 2. (Concluded)

\begin{tabular}{|c|c|c|c|c|c|c|c|c|c|}
\hline \multirow{2}{*}{\multicolumn{2}{|c|}{ Wave Height, (ft) }} & \multicolumn{8}{|c|}{ Occurrence per Wave Period (sec) } \\
\hline & & $4.4-6.0$ & $6.1-8.0$ & $8.1-10.5$ & $10.6-11.7$ & $11.8-13.3$ & $13.4-15.3$ & $\underline{15.4-18.1}$ & $\underline{\text { Total }}$ \\
\hline \multicolumn{10}{|c|}{ South-Southeast } \\
\hline $0.0-3.3$ & & -- & -. & -- & -- & -. & -. & -. & -- \\
\hline $3.3-6.6$ & & -- & 4 & -. & -. & - & -. & -. & 4 \\
\hline \multirow[t]{3}{*}{$6.6-$} & & $=$ & 1 & - & - & ․ & 1 & = & 2 \\
\hline & Total & -. & 5 & -. & -. & -- & 1 & -. & 6 \\
\hline & & & 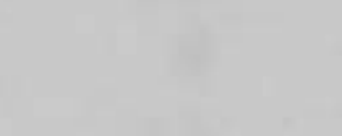 & ( & outheast &  & 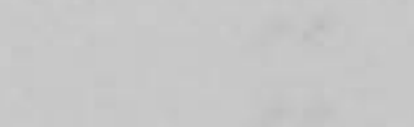 & . & \\
\hline $0.0-3.3$ & & .. & .- & .. & -. & .. & .. & .. & - \\
\hline $3.3-6.6$ & & -. & -. & -. & -- & -. & -. & -. & - \\
\hline \multirow[t]{2}{*}{$6.6-9.8$} & & 1 & $\underline{6}$ & - & 1 & - & - & 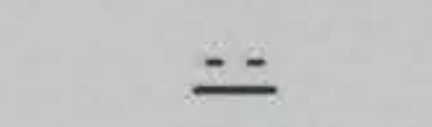 & $\underline{8}$ \\
\hline & Total & 1 & 6 & .. & 1 & -. & -. & -. & 8 \\
\hline
\end{tabular}


Table 3

Estimated Magnitude of Sheltered Deepwater Waves (Sea and Swe11) Approaching Los Angeles-Long Beach Harbors from the Directions Indicated

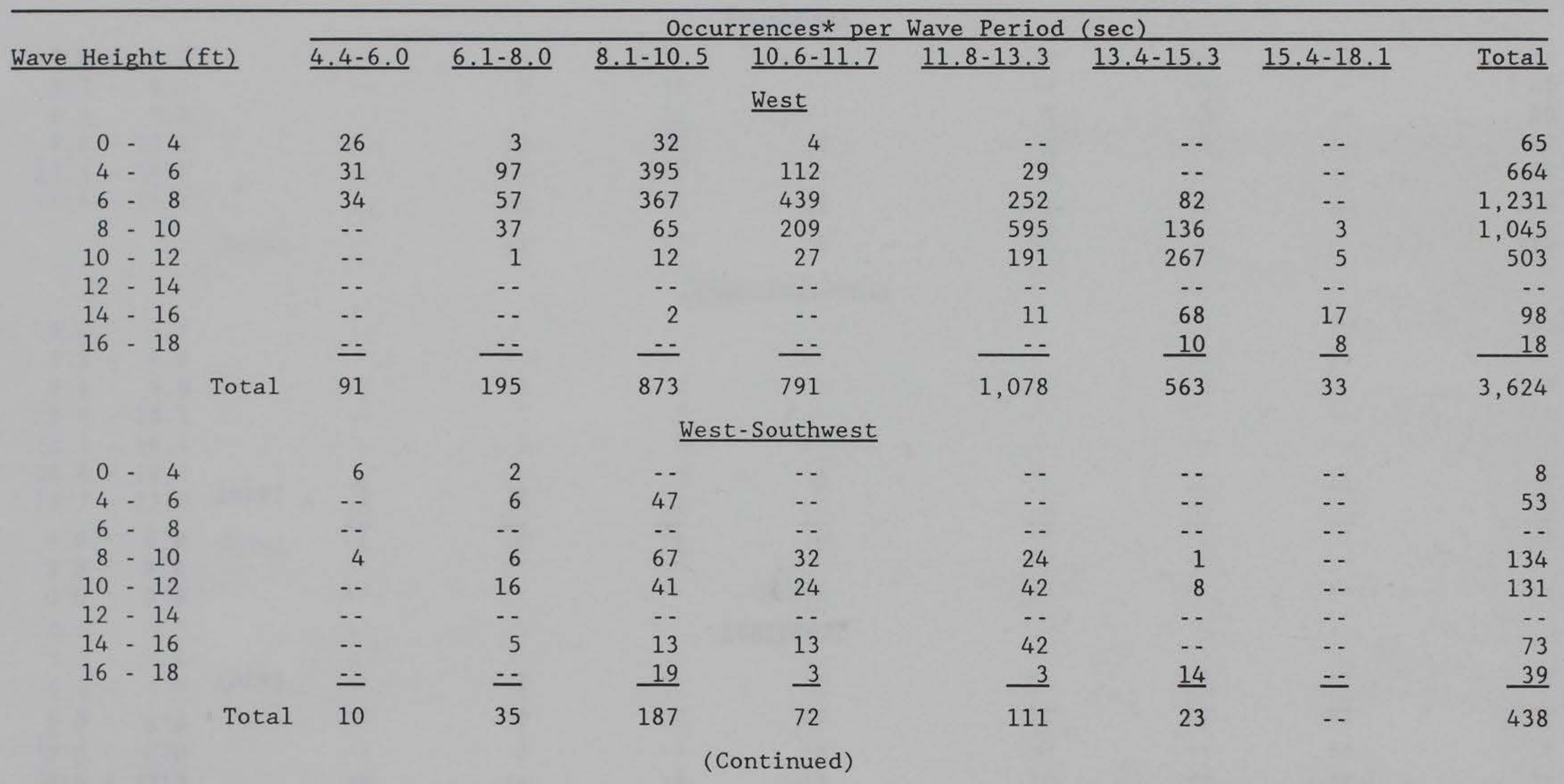

* Occurrences compiled for period 1956-1975. Each occurrence represents a 3-hr duration. 
Table 3. (Concluded)

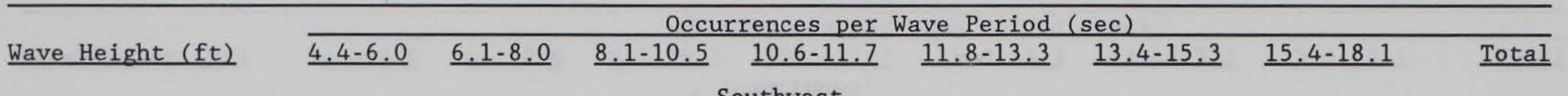
Southwest

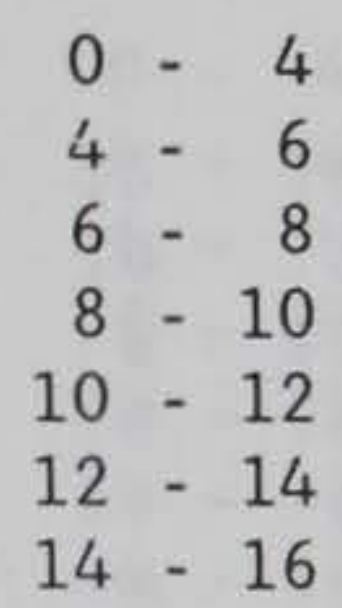

$14-16$

Total

$0-4$
$4-6$
$6-8$
$8-10$
$10-12$
$12-14$
$14-16$

Total

$0-4$
$4-6$
$6-8$

Total
-
$\cdots$
$\cdots$
$\cdots$
$\cdots$
-
-

$-$

$-$



$-\cdot$

$-$

$-$

$\underline{-}$

-.

‥

-

-
5
-
6
25
4
--
40

--
--
1
7
2
$\cdots$
--
10

10

$\begin{array}{r}-- \\ 1 \\ 4 \\ \hline 5\end{array}$

$$
\begin{gathered}
-- \\
-- \\
-- \\
- \\
-- \\
1 \\
4
\end{gathered}
$$

South-Southwest

$\begin{array}{rr}-. & -. \\ -. & -- \\ 3 & 1 \\ 7 & -- \\ 5 & -- \\ 1 & 1 \\ 4 & -- \\ 20 & 2\end{array}$

South

$\begin{array}{lr}-- & - \\ -- & 1 \\ 14 & - \\ 14 & 1\end{array}$

.-
.-
1
.-
1
--
2

1

$\frac{-}{1}$
--
--
--
5
1
--
-
6

--
--
--
--
--
-
-

21

$-$

1

5
5

-

11

$-\cdot$
-
-
-
--
--
--

--
-
2
--
--
--
2

-
$\cdots$
$\cdots$
$\cdots$
$\cdots$
$\cdots$
--

-

7

$\begin{array}{lr}- & -. \\ - & 1 \\ - & -\end{array}$

-

-

‥ 
Table 4

Estimated Magnitude of Shallow-Water Waves (Sea and Swe11) Approaching Los Angeles Harbor Entrance from the Directions Indicated

\begin{tabular}{|c|c|c|c|c|c|c|c|c|c|c|}
\hline \multirow{2}{*}{\multicolumn{3}{|c|}{ Wave Height (ft) }} & \multicolumn{8}{|c|}{ Occurrences* per Wave Period (sec) } \\
\hline & & & $4.4-6.0$ & $\underline{6.1-8.0}$ & $8.1-10.5$ & $10.6-11.7$ & $11.8-13.3$ & $13.4-15.3$ & $15.4-18.1$ & $\underline{\text { Total }}$ \\
\hline \multicolumn{11}{|c|}{ West } \\
\hline 0 & -4 & & 91 & 157 & 794 & 555 & 281 & 82 & - & 1,960 \\
\hline 4 & -6 & & - & 38 & 77 & 236 & 786 & 403 & 8 & 1,548 \\
\hline 6 & -8 & & - & $\cdots$ & $\underline{2}$ & $\cdots$ & 11 & 78 & $\underline{25}$ & 116 \\
\hline & & Total & 91 & 195 & 873 & 791 & 1,078 & 563 & 33 & 3,624 \\
\hline \multicolumn{11}{|c|}{ West-Southwest } \\
\hline 0 & -4 & & 6 & 2 & -- & -. & -. & -- & -- & 8 \\
\hline 4 & -6 & & - & 6 & 47 & - & -. & -- & -. & 53 \\
\hline 6 & -8 & & - & 6 & 67 & 56 & 66 & 9 & - - & 204 \\
\hline 8 & -10 & & 4 & 16 & 41 & - & -- & - - & - - & 61 \\
\hline 10 & -12 & & - & 5 & 13 & 16 & 45 & 14 & - - & 93 \\
\hline 12 & -14 & & ニ & = & 19 & 二 & $\cdots$ & = & - & 19 \\
\hline & & Total & 10 & 35 & 187 & 72 & 111 & 23 & - & 438 \\
\hline \multicolumn{11}{|c|}{ Southwest } \\
\hline 0 & -4 & & - & - & - & - & - & - & $\ldots$ & - \\
\hline 4 & -6 & & - - & - & 16 & - & -- & - & - & 16 \\
\hline 6 & -8 & & - & 5 & - & - - & 1 & 6 & - & 12 \\
\hline 8 & -10 & & - & 6 & 14 & 3 & 5 & - - & - & 28 \\
\hline 10 & -12 & & $\cdots$ & 25 & 13 & 1 & 5 & - - & - & 44 \\
\hline 12 & - 14 & & - & 4 & $\underline{10}$ & 三 & ㅡㅡ & $\underline{-}$ & $\underline{-}$ & 14 \\
\hline 9 & & Total & - & 40 & 53 & 4 & 11 & 6 & - & 114 \\
\hline \multicolumn{11}{|c|}{ (Continued) } \\
\hline
\end{tabular}

\footnotetext{
* Occurrences compiled for period 1956-1975. Each occurrence represents a 3-hr duration.
} 
Table 4. (Concluded)

\begin{tabular}{|c|c|c|c|c|c|c|c|c|c|c|}
\hline \multirow{2}{*}{\multicolumn{3}{|c|}{ Wave Height (ft) }} & \multicolumn{8}{|c|}{ Occurrences per Wave Period (sec) } \\
\hline & & & $4.4-6.0$ & $\underline{6.1-8.0}$ & $8.1-10.5$ & $\underline{10.6-11.7}$ & $11.8-13.3$ & $\underline{13.4-15.3}$ & $\underline{15.4-18.1}$ & Total \\
\hline \multicolumn{11}{|c|}{ South-Southwest } \\
\hline 0 & -4 & & -- & -- & -- & -. & -. & -- & -- & \\
\hline 4 & - 6 & & - & - & -. & -. & -- & - & -- & - \\
\hline 6 & - 8 & & $\cdots$ & 1 & $\cdots$ & $\because$ & $\cdots$ & 2 & -. & 3 \\
\hline 8 & -10 & & -. & 7 & 3 & 1 & -. & -. & -. & 11 \\
\hline 10 & -12 & & -. & 2 & 7 & $\cdots$ & -- & -- & $-\cdot$ & 9 \\
\hline 12 & - 14 & & $-\cdot$ & -- & 5 & $\because$ & - & $\cdots$ & -. & 5 \\
\hline 14 & -16 & & - & - & $\underline{5}$ & 1 & 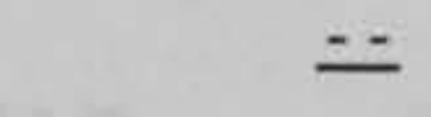 & - & - & $\underline{6}$ \\
\hline & & Total & -. & 10 & 20 & 2 & -. & 2 & - & 34 \\
\hline \multicolumn{11}{|c|}{$\underline{\text { South }}$} \\
\hline 0 & -4 & & -. & -. & -. & -. & -. & - & -. & -. \\
\hline 4 & -6 & & -. & 1 & - & 1 & -- & - & -. & 2 \\
\hline 6 & -8 & & - & 4 & 14 & $=$ & ㅍ & 1 & - & $\underline{19}$ \\
\hline & & Total & -. & 5 & 14 & 1 & - & 1 & $-\cdot$ & 21 \\
\hline \multicolumn{11}{|c|}{ South-Southeast } \\
\hline 0 & -4 & & -. & -. & -. & -. & -. & -. & -. & -. \\
\hline 4 & -6 & & $-\cdot$ & $\because$ & -. & -. & -. & -. & -. & $\because$ \\
\hline & -8 & & $-\cdot$ & 4 & .. & .. & $\cdots$ & $\overline{1}$ & - & 4 \\
\hline $\begin{array}{r}8 \\
10\end{array}$ & $\begin{array}{l}10 \\
-12\end{array}$ & & - & 1 & - & 二 & $=$ & 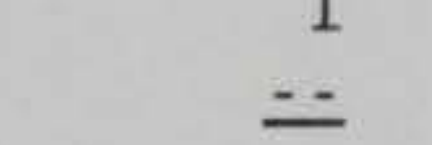 & $\cdots$ & $\begin{array}{l}1 \\
1 \\
\end{array}$ \\
\hline & & Total & -. & 5 & -. & -. & -. & $\overline{1}$ & $\begin{array}{c}- \\
-\end{array}$ & $\frac{1}{6}$ \\
\hline \multirow{2}{*}{\multicolumn{11}{|c|}{$\underline{\text { Southeast }}$}} \\
\hline 0 & -4 & & -. & -. & -. & .. & -. & .. & & \\
\hline 4 & -6 & & - - & -. & -. & -. & - & -. & -. & .. \\
\hline 6 & & & - & -. & -. & -. & -. & -. & -. & -. \\
\hline \multirow{2}{*}{\multicolumn{2}{|c|}{$8-10$}} & & 1 & $\underline{6}$ & - & 1 & - & - & $=$ & $\underline{8}$ \\
\hline & & Total & 1 & 6 & -. & 1 & -. & -. & -. & 8 \\
\hline
\end{tabular}


Table 5

Wave Heights for Plans 1-13 for Test Waves

from $90 \mathrm{deg}$

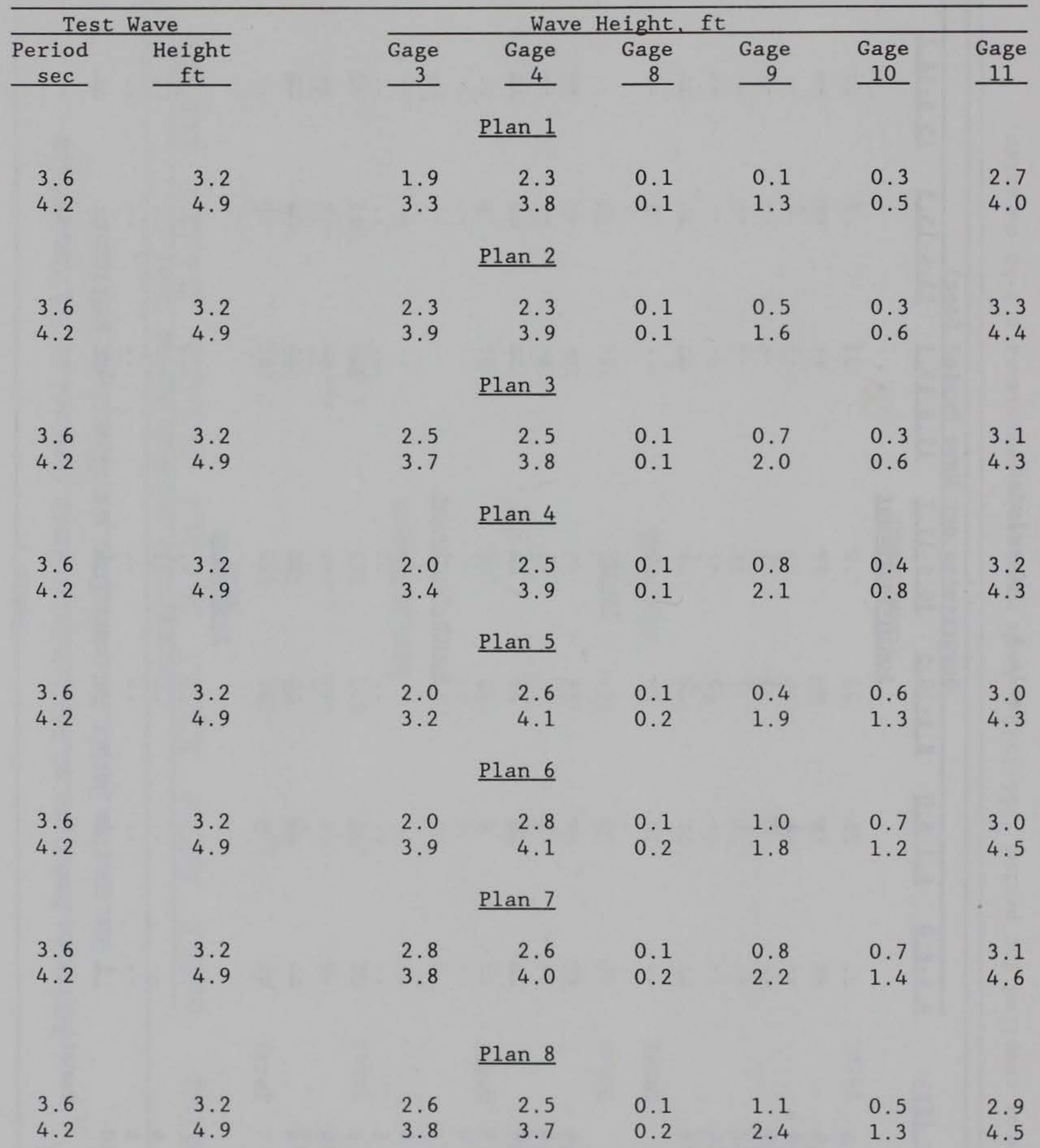

(Continued) 
Table 5. (Concluded)

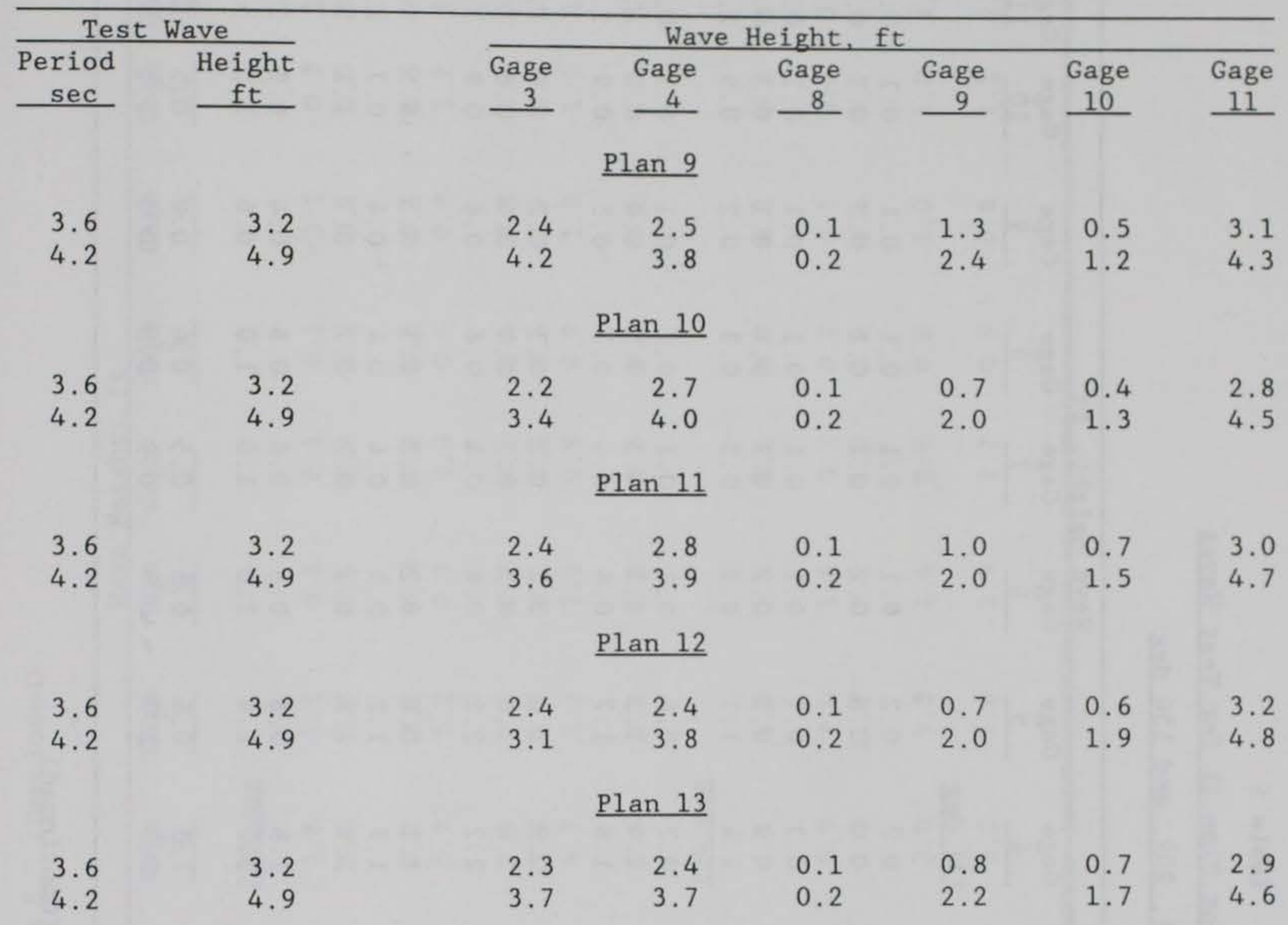


Table 6

Wave Heights for Plan 11 for Test Waves

from 231, 209, and $154 \mathrm{deg}$

\begin{tabular}{|c|c|c|c|c|c|c|c|c|c|c|c|c|}
\hline \multicolumn{2}{|c|}{ Test Wave } & & & \multicolumn{9}{|c|}{ Wave Height, $\mathrm{ft}$} \\
\hline $\begin{array}{c}\text { Period } \\
\text { sec } \\
\end{array}$ & $\begin{array}{c}\text { Height } \\
\mathrm{ft}\end{array}$ & $\begin{array}{c}\text { Gage } \\
1 \\
\end{array}$ & $\begin{array}{r}\text { Gage } \\
2 \\
\end{array}$ & $\begin{array}{r}\text { Gage } \\
\quad 3 \\
\end{array}$ & $\begin{array}{c}\text { Gage } \\
\quad 4 \\
\end{array}$ & $\begin{array}{c}\text { Gage } \\
5 \\
\end{array}$ & $\begin{array}{l}\text { Gage } \\
\quad 6 \\
\end{array}$ & $\begin{array}{c}\text { Gage } \\
7 \\
\end{array}$ & $\begin{array}{c}\text { Gage } \\
8 \\
\end{array}$ & $\begin{array}{l}\text { Gage } \\
9 \\
\end{array}$ & $\begin{array}{c}\text { Gage } \\
10 \\
\end{array}$ & $\begin{array}{c}\text { Gage } \\
\underline{11} \\
\end{array}$ \\
\hline & & & & & $\underline{231 \mathrm{~d}}$ & & & & & & & \\
\hline \multirow[t]{2}{*}{5} & 4 & 2.9 & 0.1 & 0.2 & 0.2 & 0.2 & 0.1 & 0.1 & 0.1 & 0.1 & 0.1 & 0.2 \\
\hline & 10 & 7.5 & 0.2 & 0.4 & 0.6 & 0.8 & 0.2 & 0.2 & 0.1 & 0.2 & 0.1 & 0.7 \\
\hline \multirow[t]{3}{*}{7} & 4 & 3.0 & 0.1 & 0.2 & 0.3 & 0.1 & 0.1 & 0.1 & 0.1 & 0.1 & 0.1 & 0.2 \\
\hline & 10 & 9.3 & 0.3 & 0.6 & 0.9 & 0.5 & 0.2 & 0.2 & 0.1 & 0.1 & 0.3 & 0.8 \\
\hline & 14 & 12.5 & 0.5 & 0.8 & 1.4 & 1.1 & 0.3 & 0.3 & 0.3 & 0.2 & 0.5 & 1.6 \\
\hline \multirow[t]{3}{*}{9} & 4 & 4.8 & 0.2 & 0.5 & 0.7 & 0.6 & 0.1 & 0.1 & 0.2 & 0.1 & 0.3 & 0.8 \\
\hline & 10 & 10.9 & 0.5 & 0.9 & 1.4 & 1.3 & 0.3 & 0.3 & 0.5 & 0.4 & 0.8 & 1.8 \\
\hline & 14 & 13.3 & 0.7 & 1.1 & 1.8 & 1.7 & 0.4 & 0.4 & 0.7 & 0.5 & 0.9 & 2.3 \\
\hline \multirow[t]{3}{*}{11} & 4 & 4.7 & 0.3 & 0.4 & 0.9 & 1.0 & 0.2 & 0.2 & 0.3 & 0.2 & 0.4 & 1.1 \\
\hline & 8 & 9.4 & 0.6 & 0.7 & 1.6 & 1.6 & 0.3 & 0.3 & 0.4 & 0.4 & 0.6 & 1.9 \\
\hline & 12 & 12.5 & 1.0 & 1.1 & 2.2 & 2.2 & 0.4 & 0.4 & 0.6 & 0.6 & 0.9 & 3.0 \\
\hline \multirow[t]{3}{*}{13} & 4 & 5.2 & 0.7 & 0.6 & 1.1 & 0.8 & 0.2 & 0.3 & 0.3 & 0.3 & 0.5 & 1.5 \\
\hline & 8 & 7.9 & 1.0 & 0.9 & 1.7 & 1.2 & 0.3 & 0.4 & 0.4 & 0.4 & 0.7 & 2.3 \\
\hline & 12 & 11.6 & 1.6 & 1.5 & 2.5 & 1.8 & 0.7 & 0.7 & 0.7 & 0.7 & 1.1 & 3.3 \\
\hline \multirow[t]{2}{*}{15} & 6 & 6.3 & 1.2 & 1. 2 & 1.8 & 0.8 & 0.6 & 0.6 & 0.5 & 0.4 & 0.8 & 2.4 \\
\hline & 12 & 11.0 & 2.1 & 2.0 & 3.0 & 1.4 & 1.0 & 1.0 & 1.0 & 0.6 & 1.5 & 3.9 \\
\hline \multirow[t]{2}{*}{17} & 4 & 4.0 & 1.0 & 1.2 & 1.3 & 0.6 & 0.5 & 0.5 & 0.4 & 0.2 & 0.5 & 1.7 \\
\hline & 8 & 8.0 & 2.0 & 2.4 & 2.5 & 1.3 & 0.9 & 0.9 & 0.8 & 0.5 & 1.1 & 3.1 \\
\hline
\end{tabular}


Table 6. (Concluded)

\begin{tabular}{|c|c|c|c|c|c|c|c|c|c|c|c|c|}
\hline \multicolumn{2}{|c|}{ Test Wave } & & & \multicolumn{9}{|c|}{ Wave Height, $\mathrm{ft}$} \\
\hline $\begin{array}{c}\text { Period } \\
\text { sec } \\
\end{array}$ & $\begin{array}{c}\text { Height } \\
\mathrm{ft}\end{array}$ & $\begin{array}{c}\text { Gage } \\
1 \\
\end{array}$ & $\begin{array}{c}\text { Gage } \\
2 \\
\end{array}$ & $\begin{array}{c}\text { Gage } \\
3 \\
\end{array}$ & $\begin{array}{c}\text { Gage } \\
4 \\
\end{array}$ & $\begin{array}{c}\text { Gage } \\
5 \\
\end{array}$ & $\begin{array}{c}\text { Gage } \\
6 \\
\end{array}$ & $\begin{array}{c}\text { Gage } \\
7 \\
\end{array}$ & $\begin{array}{c}\text { Gage } \\
8 \\
\end{array}$ & $\begin{array}{c}\text { Gage } \\
9 \\
\end{array}$ & $\begin{array}{c}\text { Gage } \\
10\end{array}$ & $\begin{array}{c}\text { Gage } \\
11\end{array}$ \\
\hline & & & & & $\underline{209 d f}$ & & & & & & & \\
\hline \multirow[t]{2}{*}{7} & 8 & 4.9 & 0.3 & 0.3 & 1.8 & 1.1 & 0.2 & 0.1 & 0.1 & $<0.1$ & 0.3 & 2.2 \\
\hline & 12 & 8.1 & 0.6 & 0.6 & 3.0 & 2.3 & 0.4 & 0.2 & 0.2 & 0.1 & 0.5 & 3.4 \\
\hline \multirow[t]{2}{*}{9} & 8 & 5.8 & 0.4 & 0.6 & 2.2 & 2.7 & 0.3 & 0.2 & 0.3 & 0.1 & 0.6 & 2.9 \\
\hline & 16 & 11.0 & 1.1 & 1.4 & 5.2 & 5.2 & 0.9 & 0.6 & 0.6 & 0.8 & 1.2 & 5.5 \\
\hline \multirow[t]{3}{*}{11} & 6 & 4.0 & 0.3 & 0.5 & 1.3 & 2.5 & 0.2 & 0.1 & 0.4 & 0.3 & 0.7 & 2.4 \\
\hline & 10 & 6.7 & 0.6 & 0.9 & 2.9 & 3.9 & 0.4 & 0.3 & 0.6 & 0.7 & 0.8 & 4.1 \\
\hline & 16 & 10.4 & 1.5 & 1.9 & 4.7 & 5.7 & 1.3 & 0.9 & 0.9 & 1.2 & 1.5 & 6.7 \\
\hline \multirow[t]{2}{*}{15} & 8 & 4.7 & 1.1 & 1.3 & 2.6 & 2.2 & 0.8 & 0.6 & 0.8 & 0.6 & 1.5 & 3.6 \\
\hline & \multicolumn{12}{|c|}{$\underline{154 \mathrm{deg}}$} \\
\hline 5 & 10 & 7.9 & 0.7 & 1.0 & 1.1 & 8.3 & 1.6 & 0.8 & 0.2 & 0.2 & 0.5 & 0.8 \\
\hline \multirow[t]{2}{*}{7} & 8 & 6.4 & 0.7 & 0.8 & 0.9 & 7.0 & 1.6 & 0.7 & 0.2 & 0.1 & 0.3 & 0.9 \\
\hline & 12 & 11.3 & 1.1 & 1.2 & 1.3 & 11.2 & 2.2 & 1.0 & 0.2 & 0.5 & 0.7 & 1.4 \\
\hline 11 & 10 & 12.6 & 1.5 & 1.5 & 3.0 & 9.8 & 1.6 & 0.9 & 0.6 & 1.0 & 1.0 & 1.8 \\
\hline 15 & 10 & 10.1 & 2.2 & 1.5 & 3.2 & 5.9 & 3.9 & 2.7 & 0.8 & 0.8 & 1.1 & 2.1 \\
\hline
\end{tabular}


Table 7

Wave Heights for Plan 14 for Test Waves

from 231, 209, and $154 \mathrm{deg}$

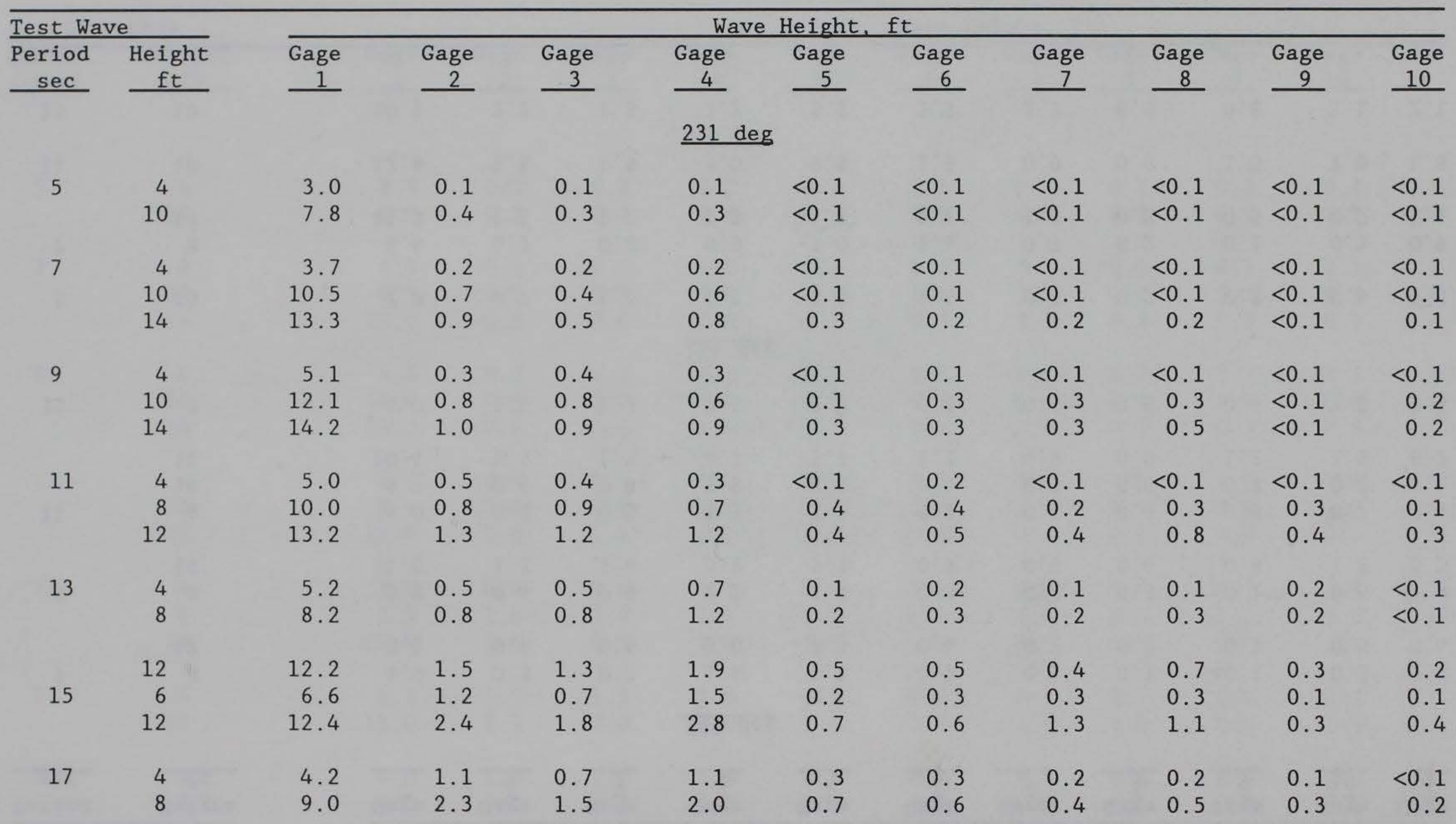


Table 7. (Concluded)

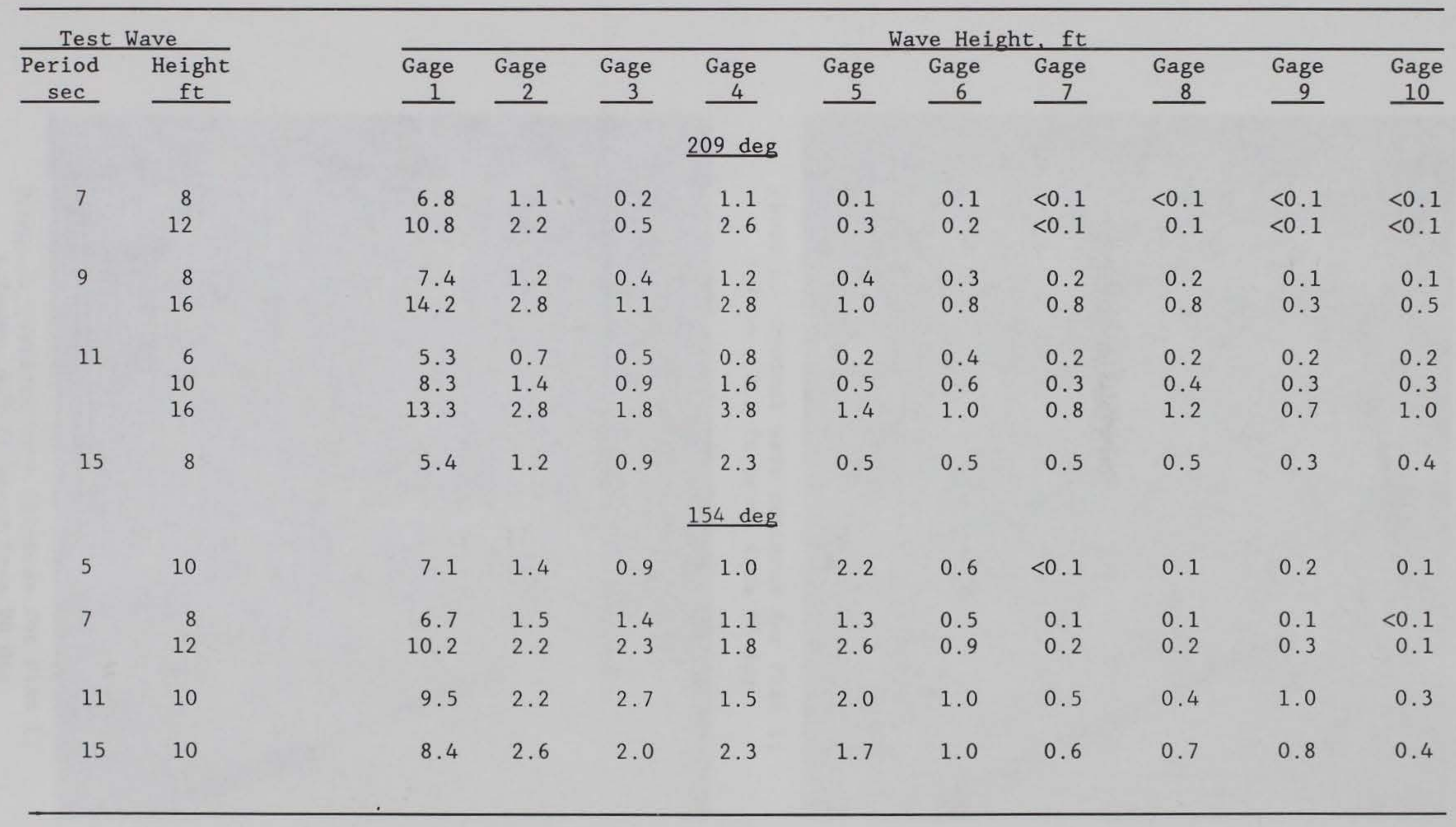




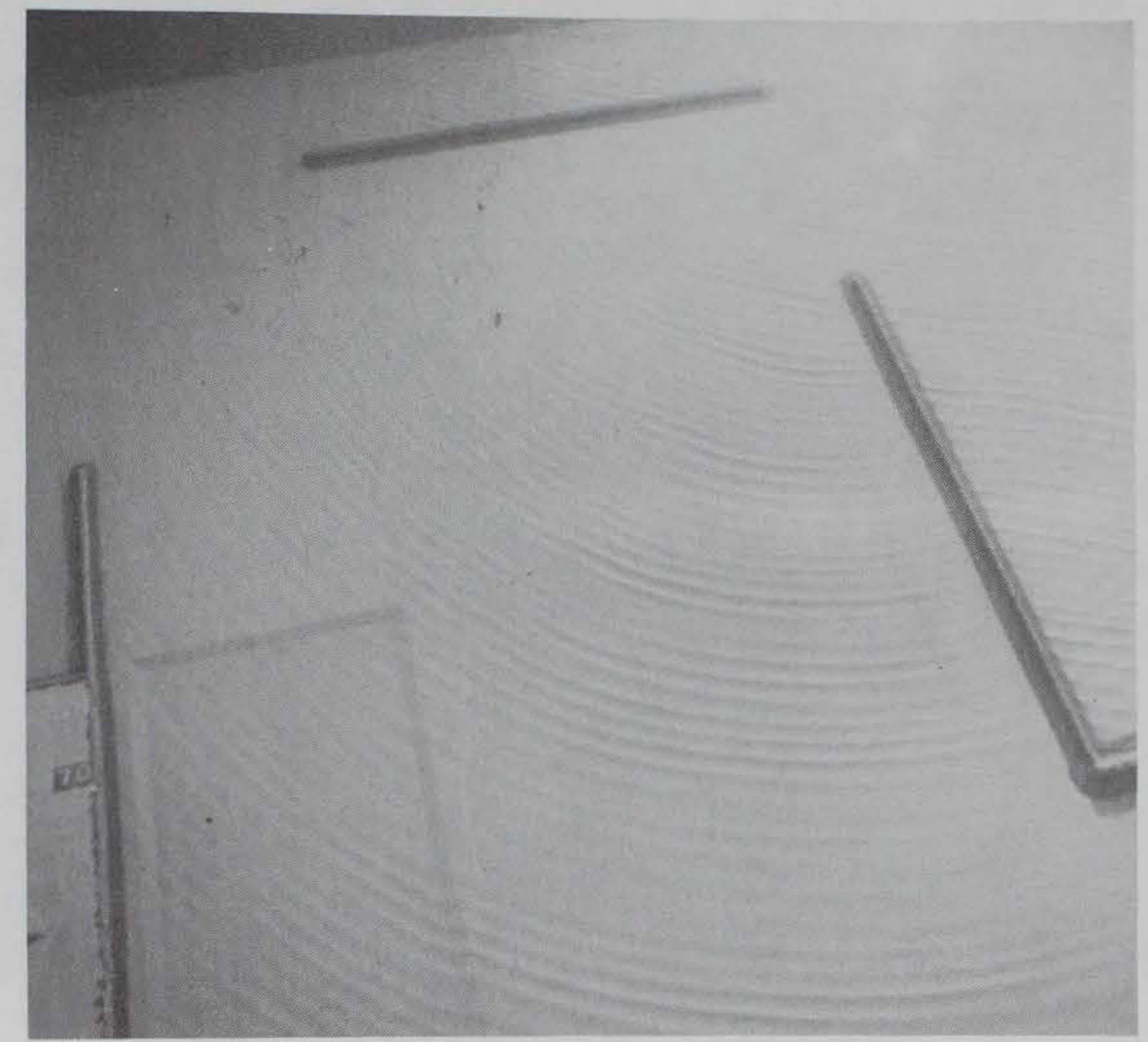

Photo 1. Typical wave patterns for Plan 1; $3.6-\mathrm{sec}, 3.2 \mathrm{ft}$ waves from $90 \mathrm{deg}$

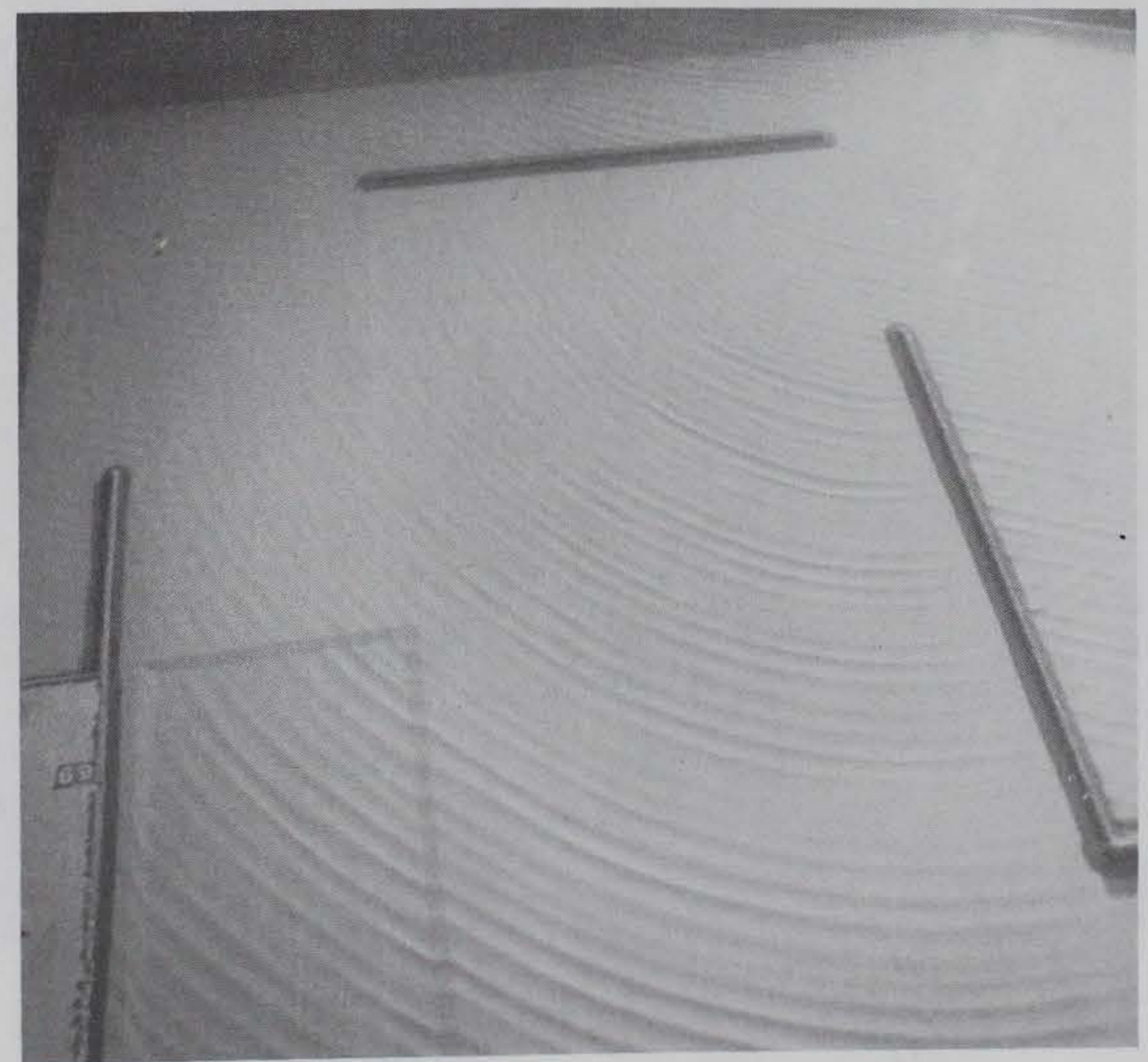

Photo 2. Typical wave patterns for Plan 1; 4.2-sec, 4.9-ft waves from $90 \mathrm{deg}$ 


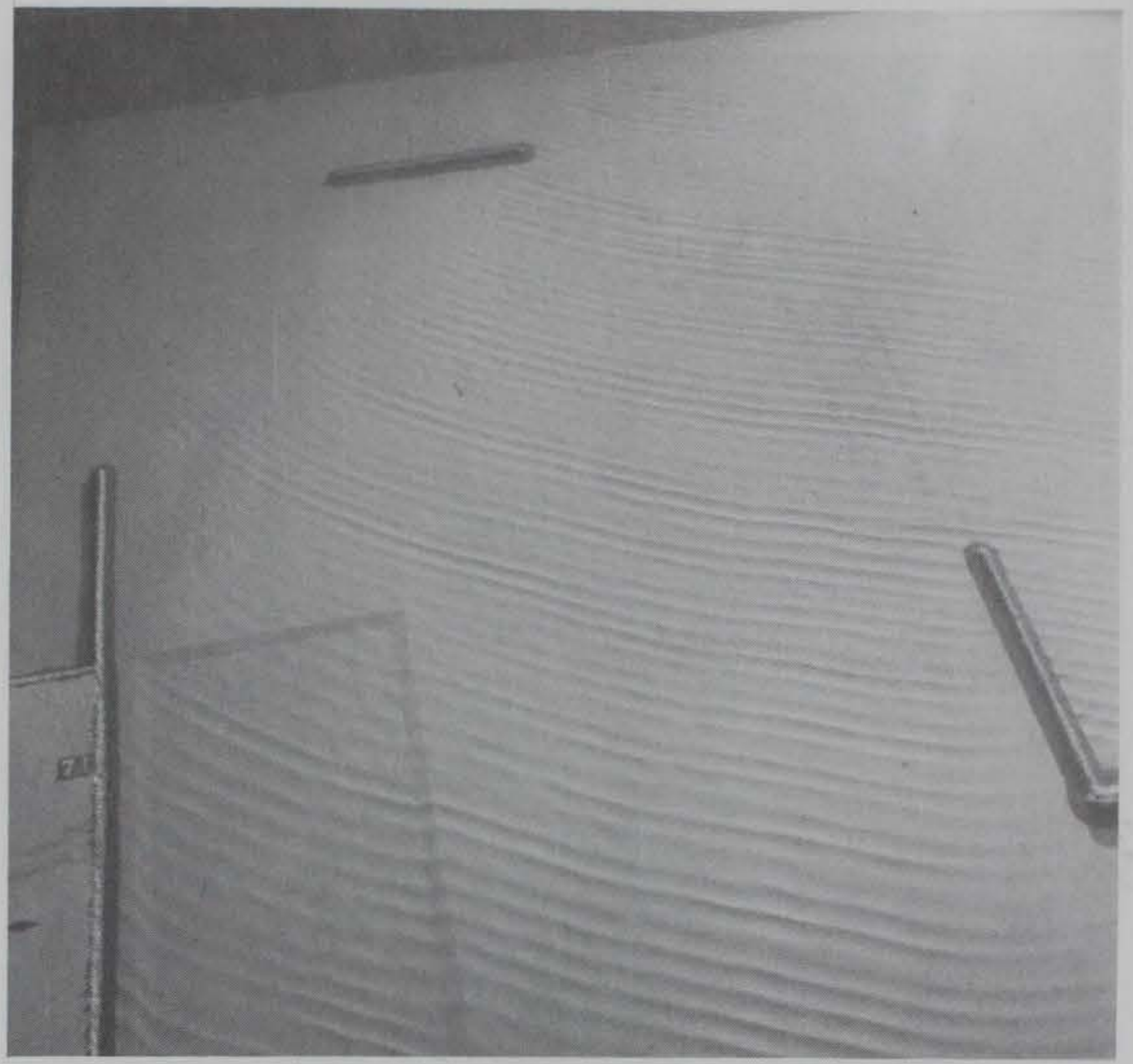

Photo 3. Typical wave patterns for P1an 11; $3.6-\mathrm{sec}, 3.2-\mathrm{ft}$ waves from $90 \mathrm{deg}$

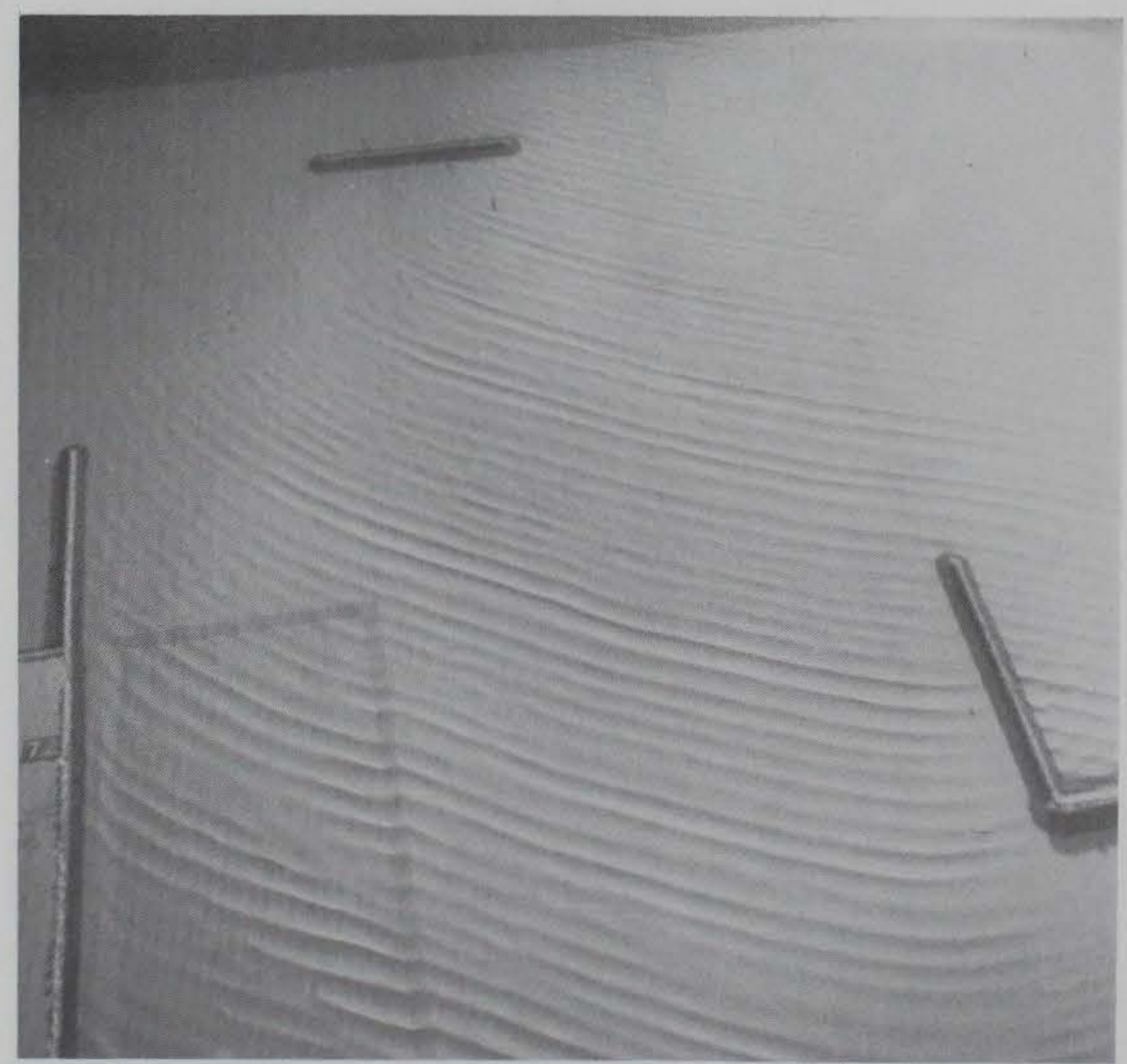

Photo 4. Typical wave patterns for Plan 11; 4.2-sec, 4.9-ft waves from $90 \mathrm{deg}$ 


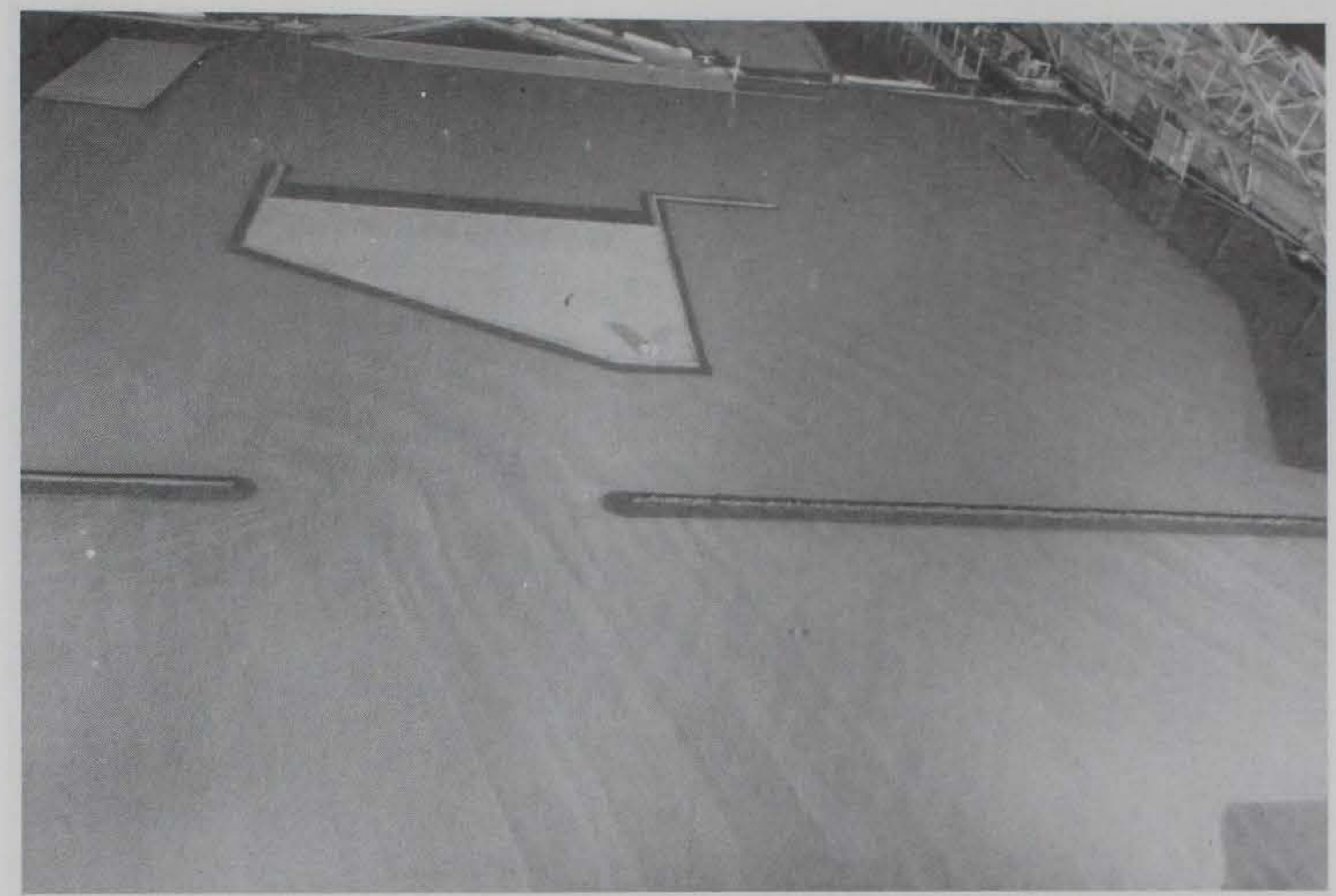

Photo 5. Typical wave patterns for Plan 11; $11-\mathrm{sec}, 8-\mathrm{ft}$ waves from $231 \mathrm{deg}$

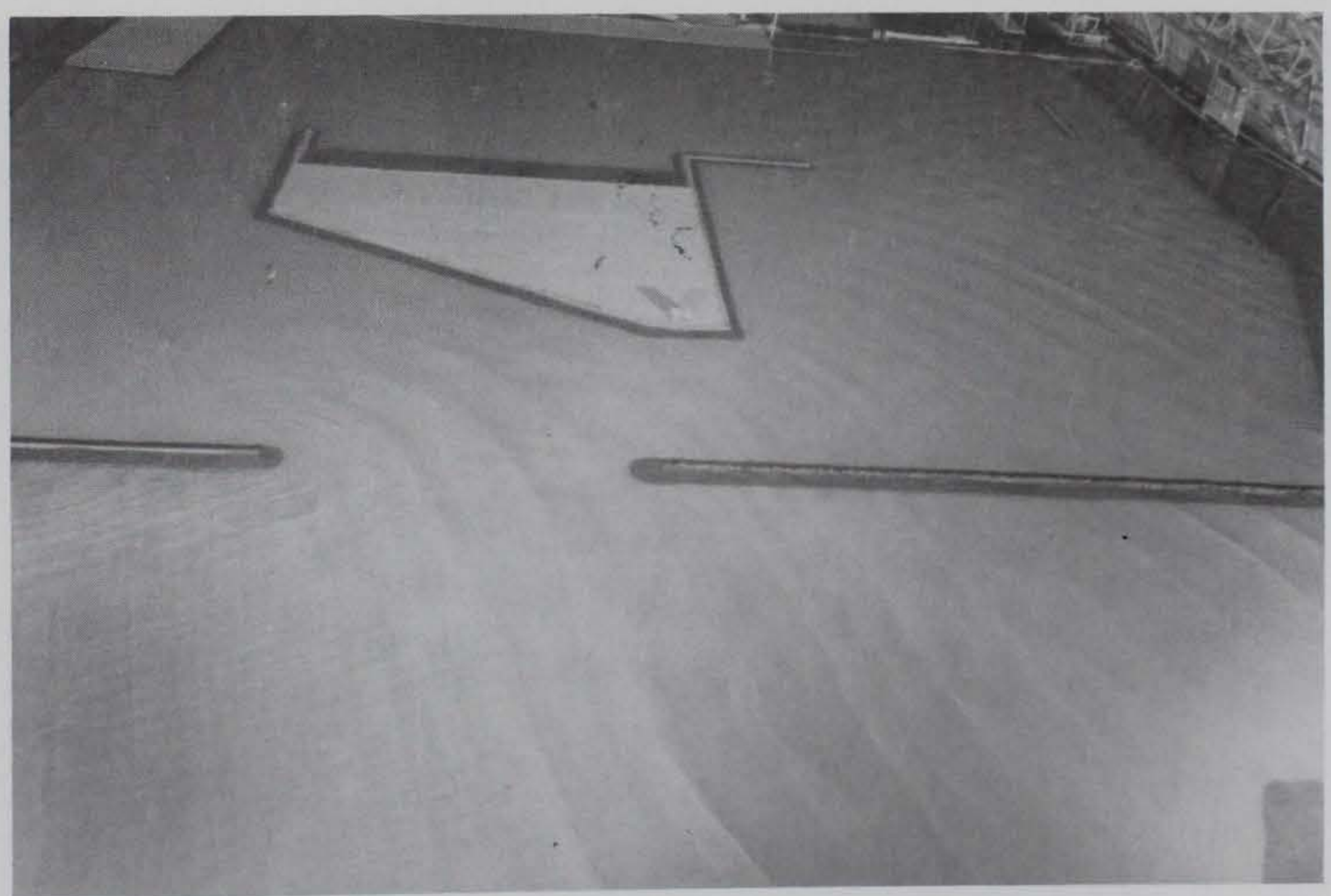

Photo 6. Typical wave patterns for Plan 11; $13-\mathrm{sec}, 12-\mathrm{ft}$ waves from $231 \mathrm{deg}$ 


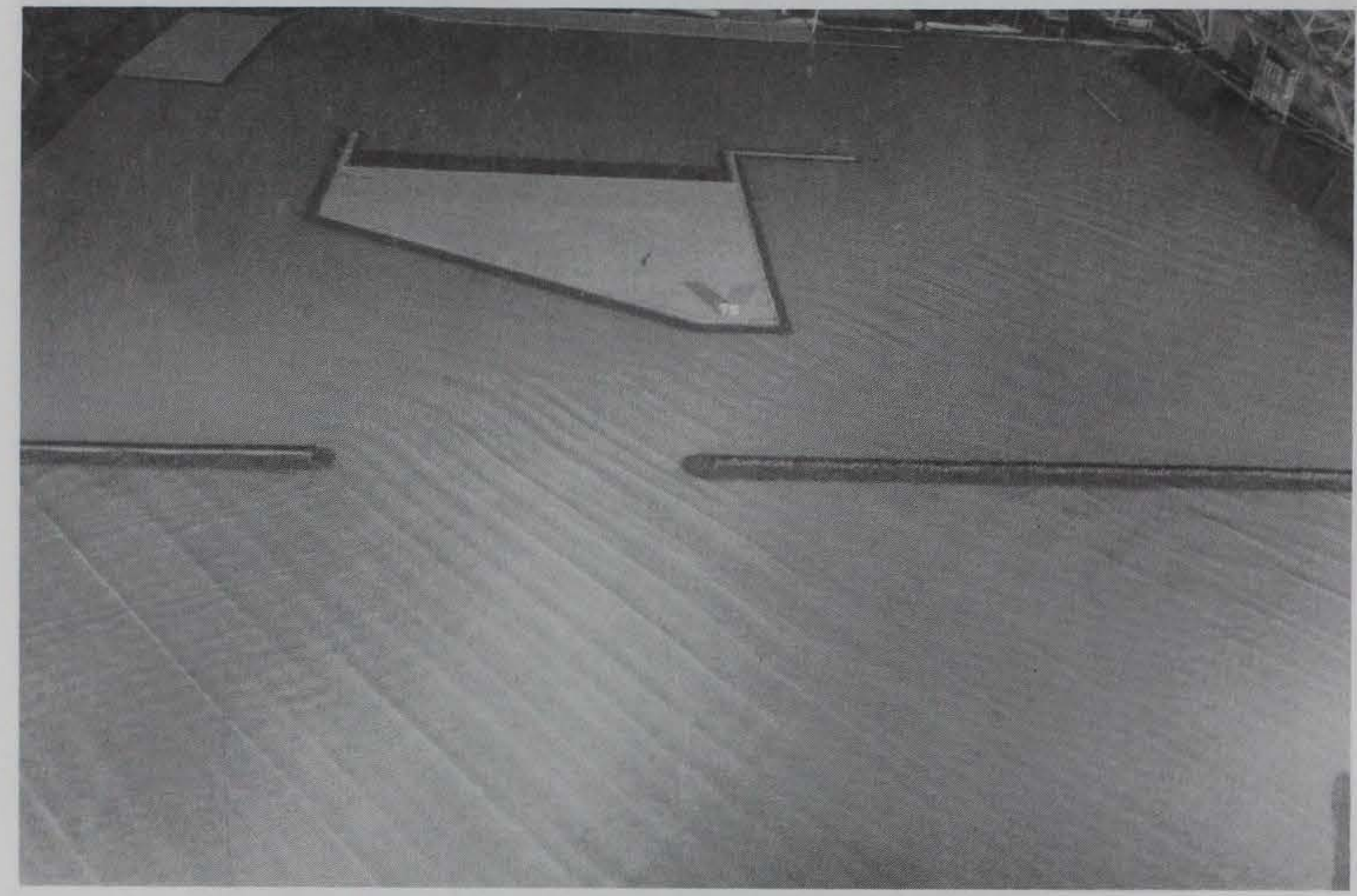

Photo 7. Typical wave patterns for Plan 11;

9-sec, 8-ft waves from $209 \mathrm{deg}$



Photo 8. Typical wave patterns for P1an 11; $11-\mathrm{sec}, 16-\mathrm{ft}$ waves from $209 \mathrm{deg}$ 


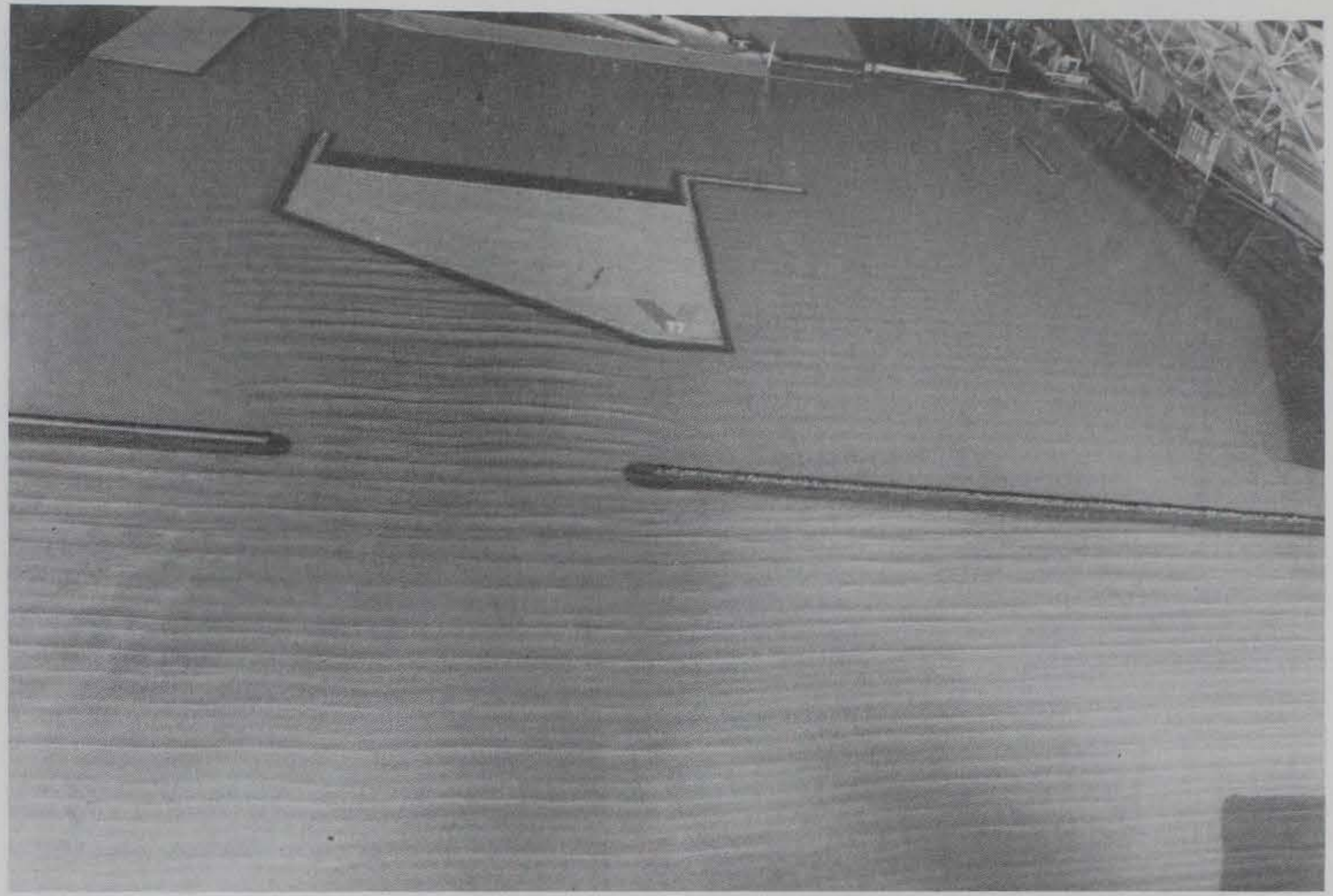

Photo 9. Typical wave patterns for Plan 11;

7-sec, 8-ft waves from $154 \mathrm{deg}$

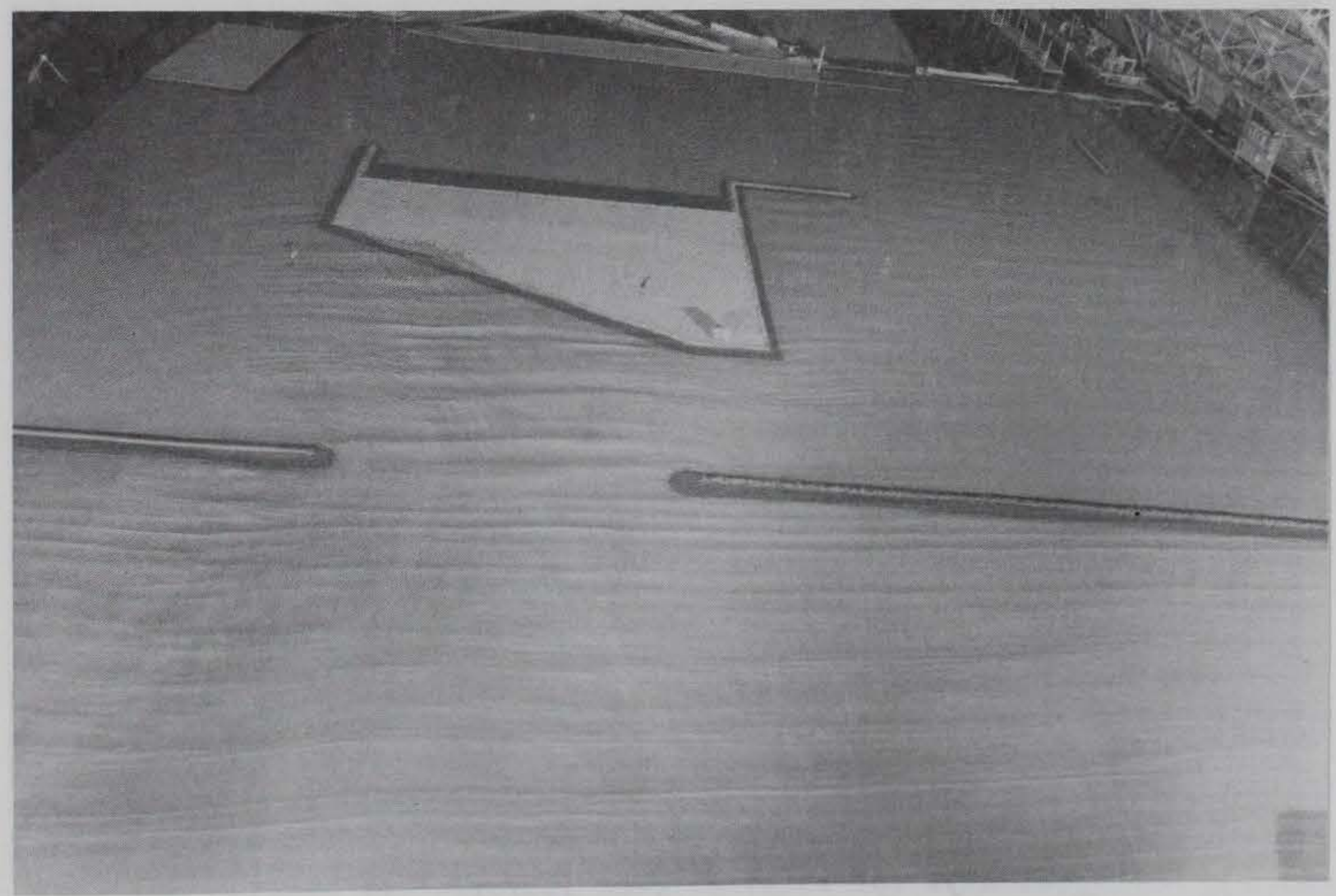

Photo 10. Typical wave patterns for Plan 11;

$11-\mathrm{sec}, 10-\mathrm{ft}$ waves from $154 \mathrm{deg}$ 


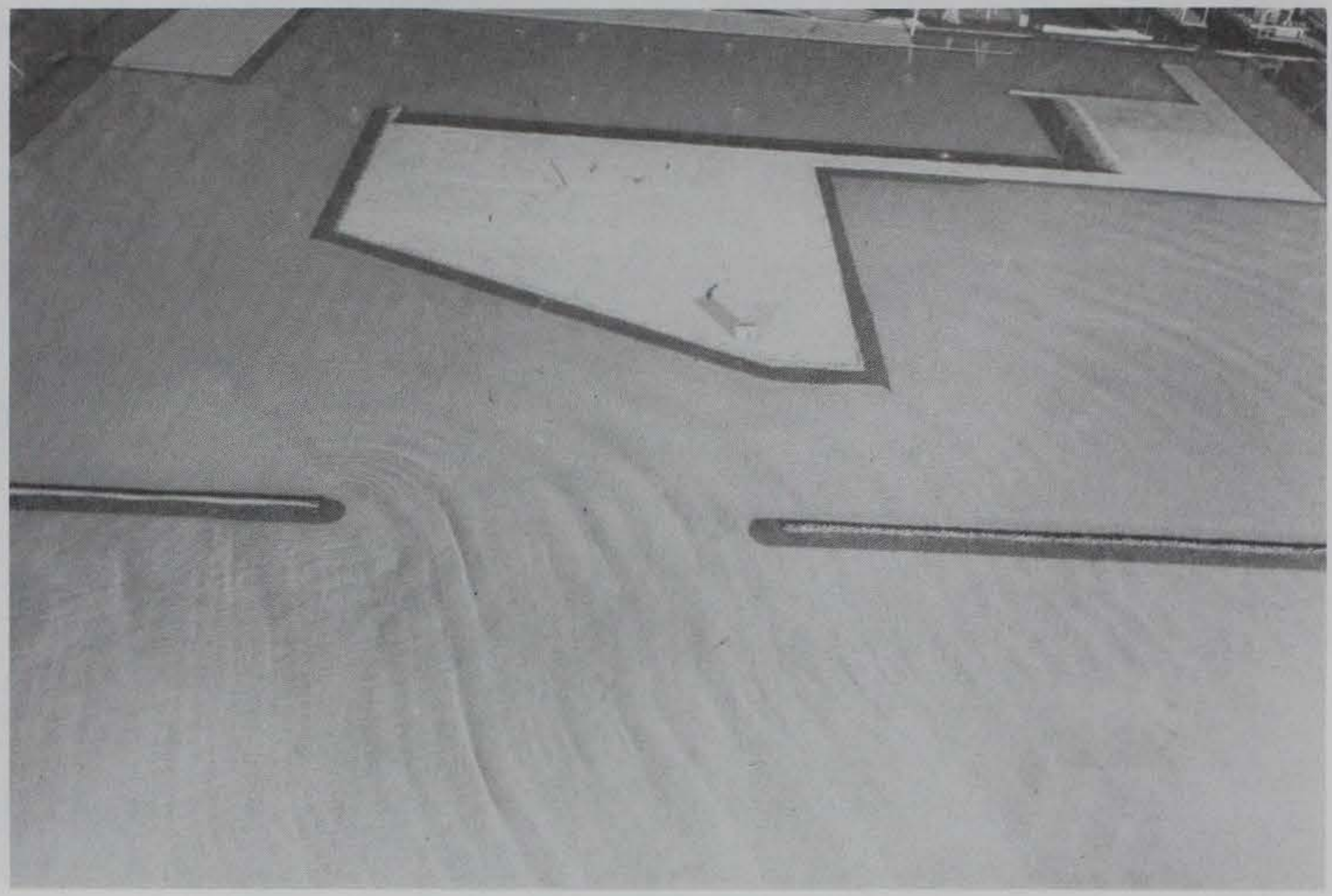

Photo 11. Typical wave patterns for Plan 14;

$11-\mathrm{sec}, 8-\mathrm{ft}$ waves from $231 \mathrm{deg}$

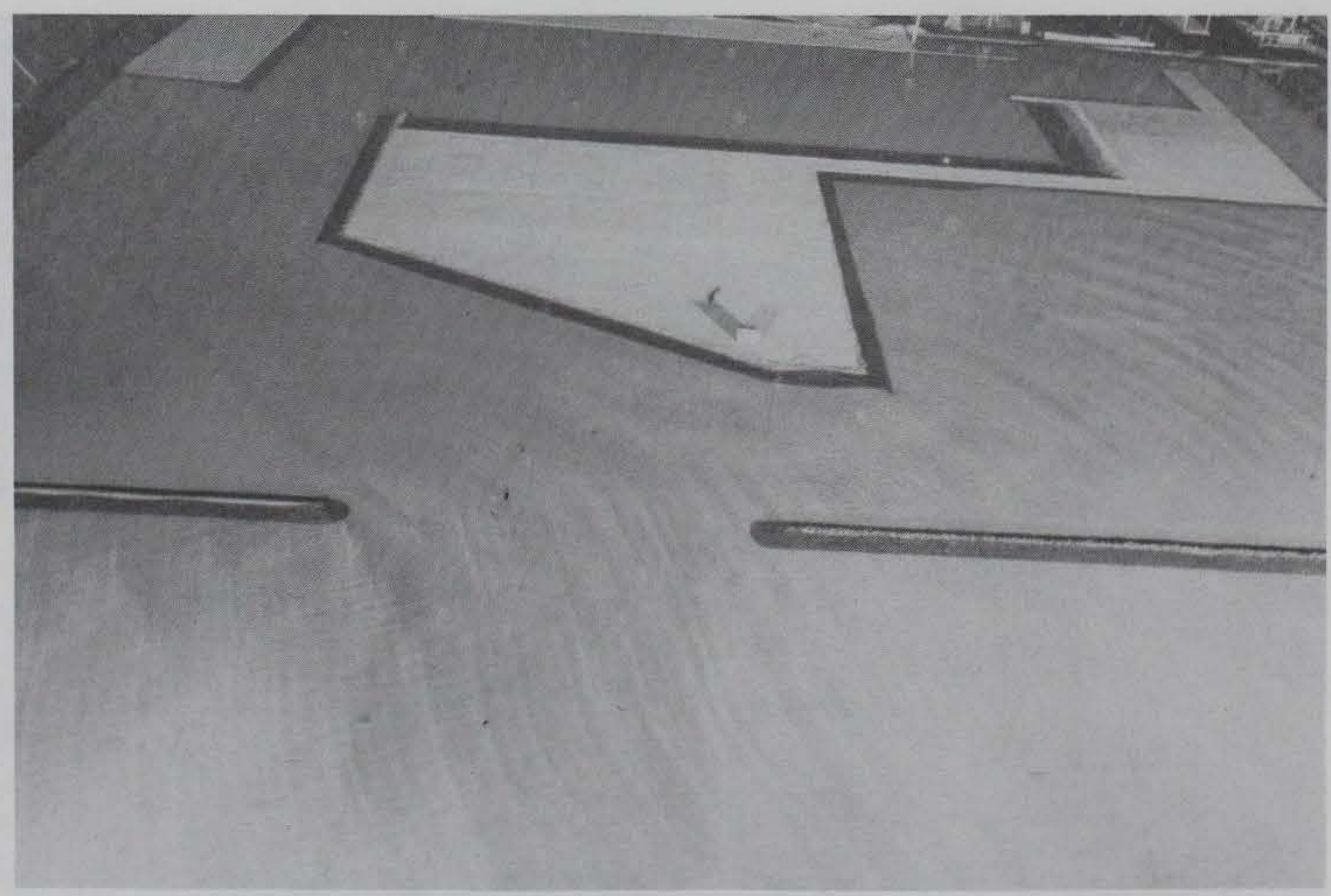

Photo 12. Typical wave patterns for Plan 14;

$13-\mathrm{sec}, 12-\mathrm{ft}$ waves from $231 \mathrm{deg}$ 


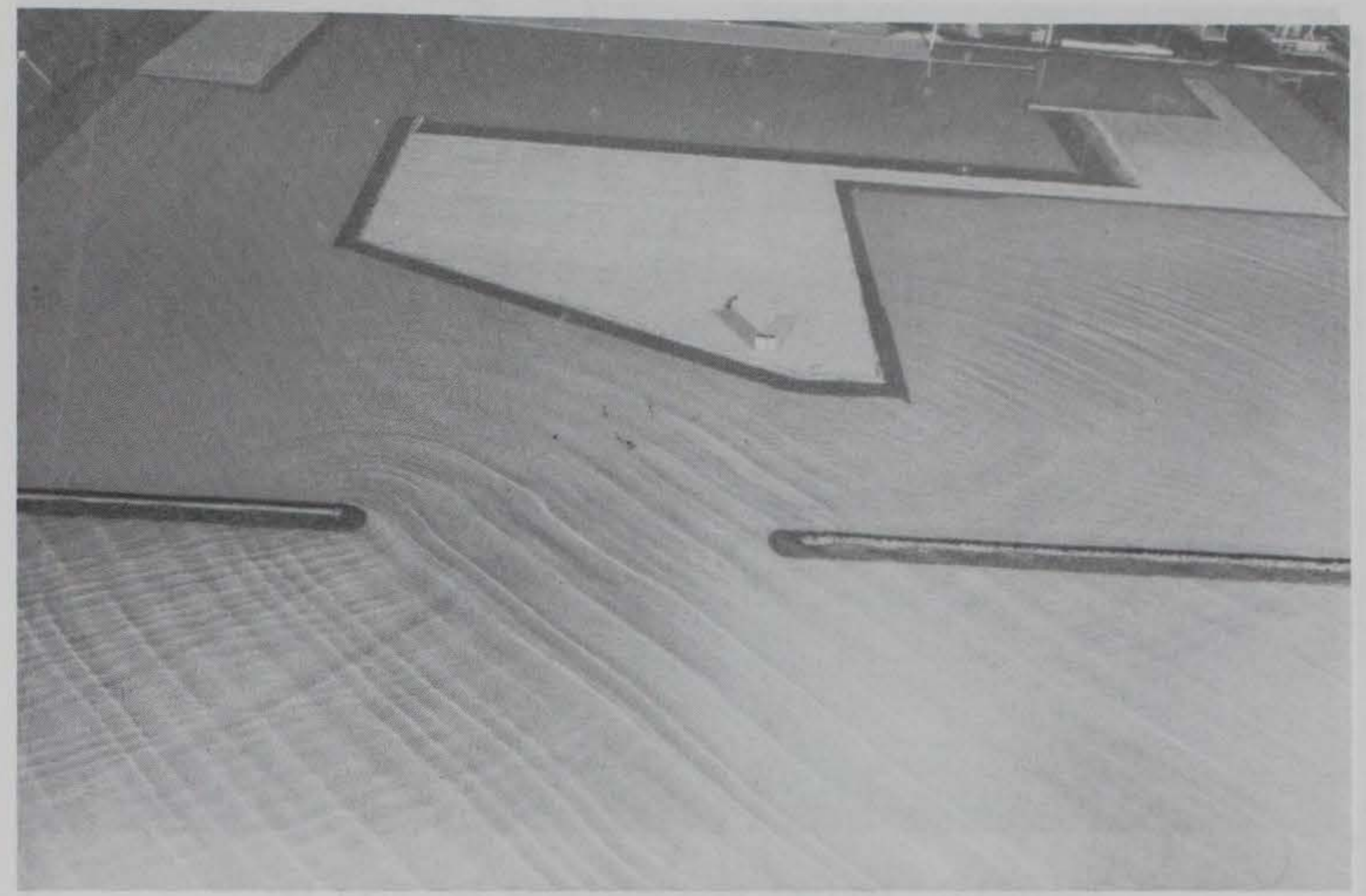

Photo 13. Typical wave patterns for Plan 14; 9-sec, 8-ft waves from 209 deg

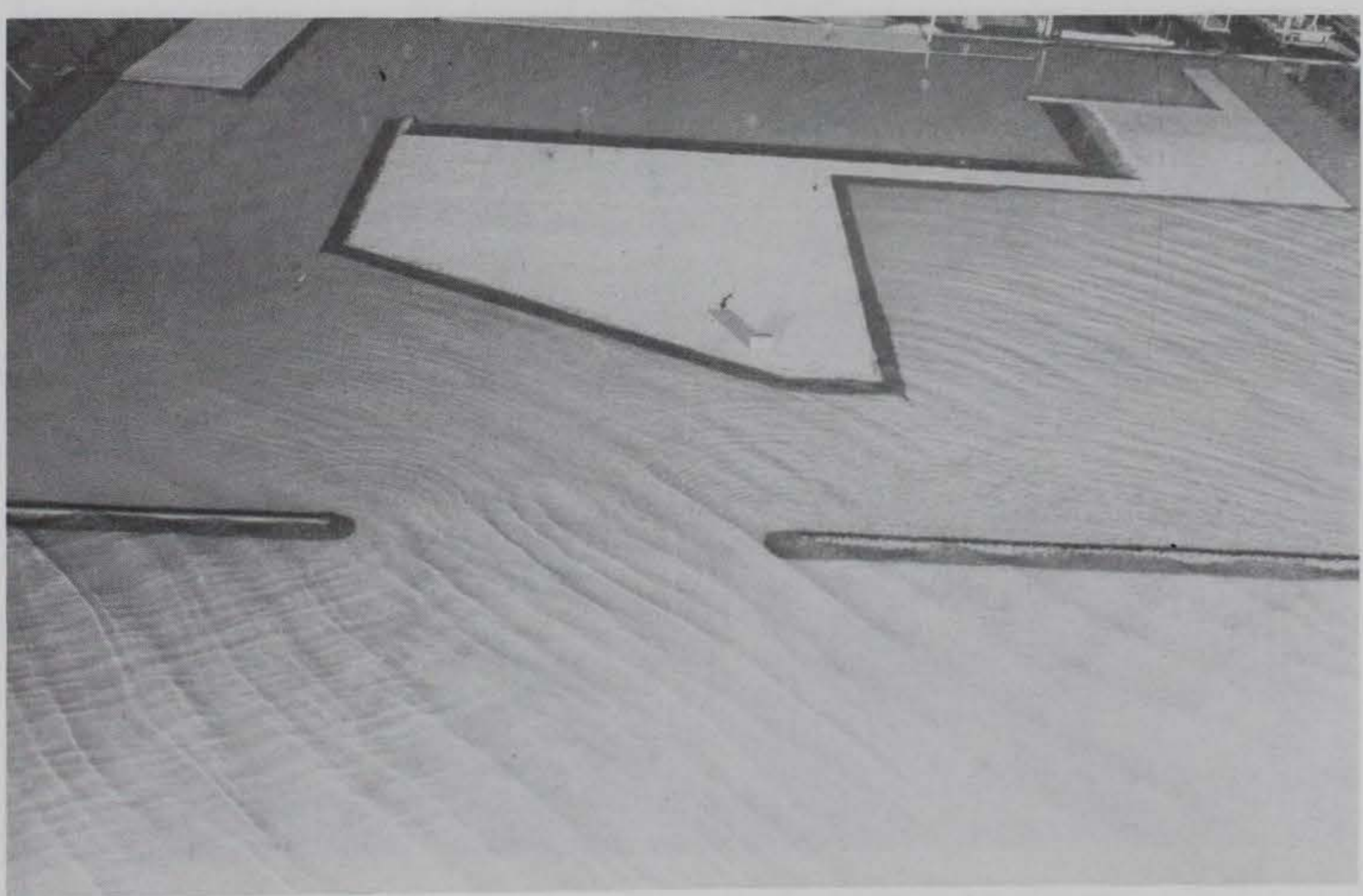

Photo 14. Typical wave patterns for Plan 14; $11-\mathrm{sec}, 16-\mathrm{ft}$ waves from $209 \mathrm{deg}$ 


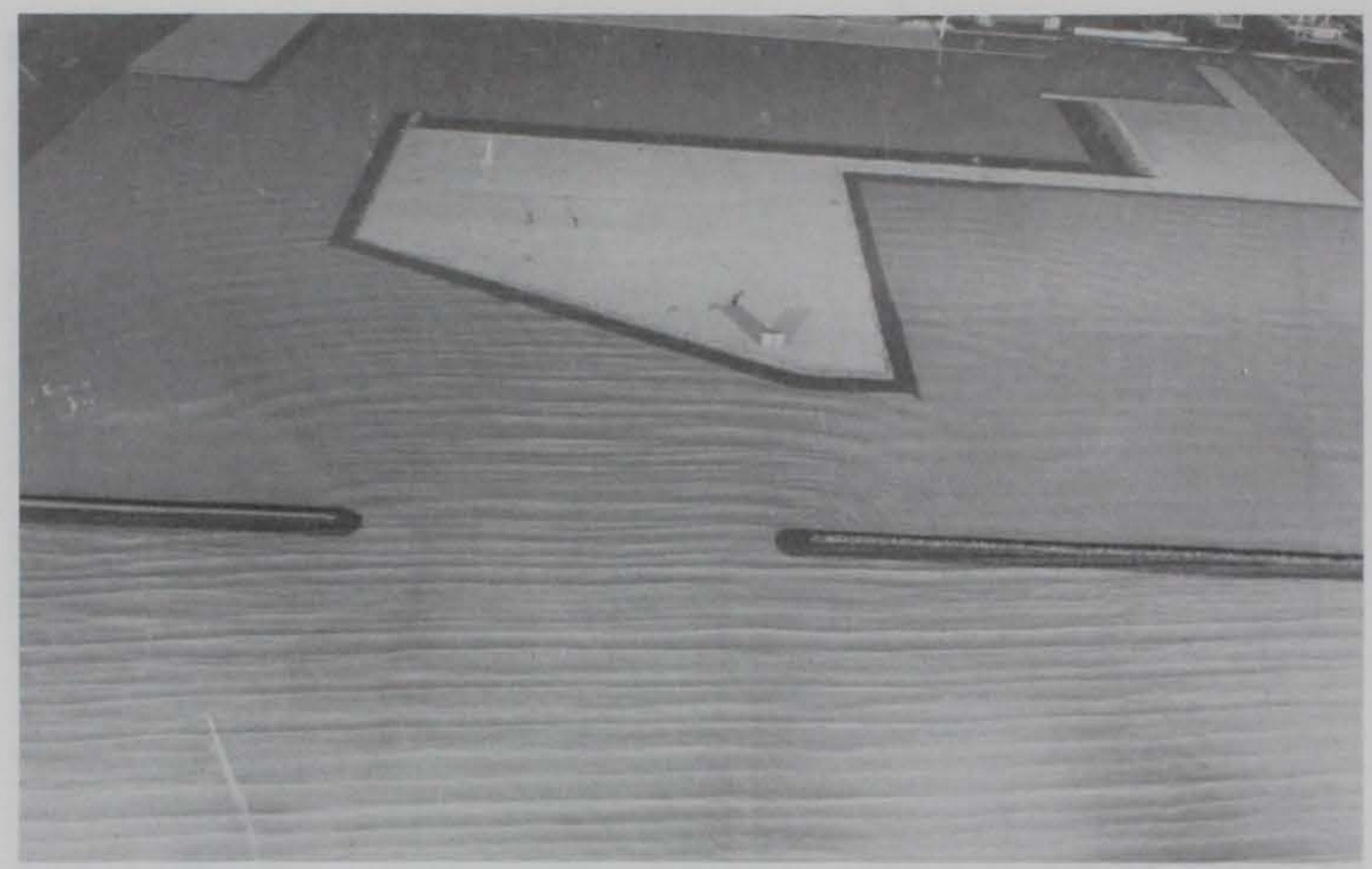

Photo 15. Typical wave patterns for Plan 14; 7-sec, 8-ft waves from $154 \mathrm{deg}$

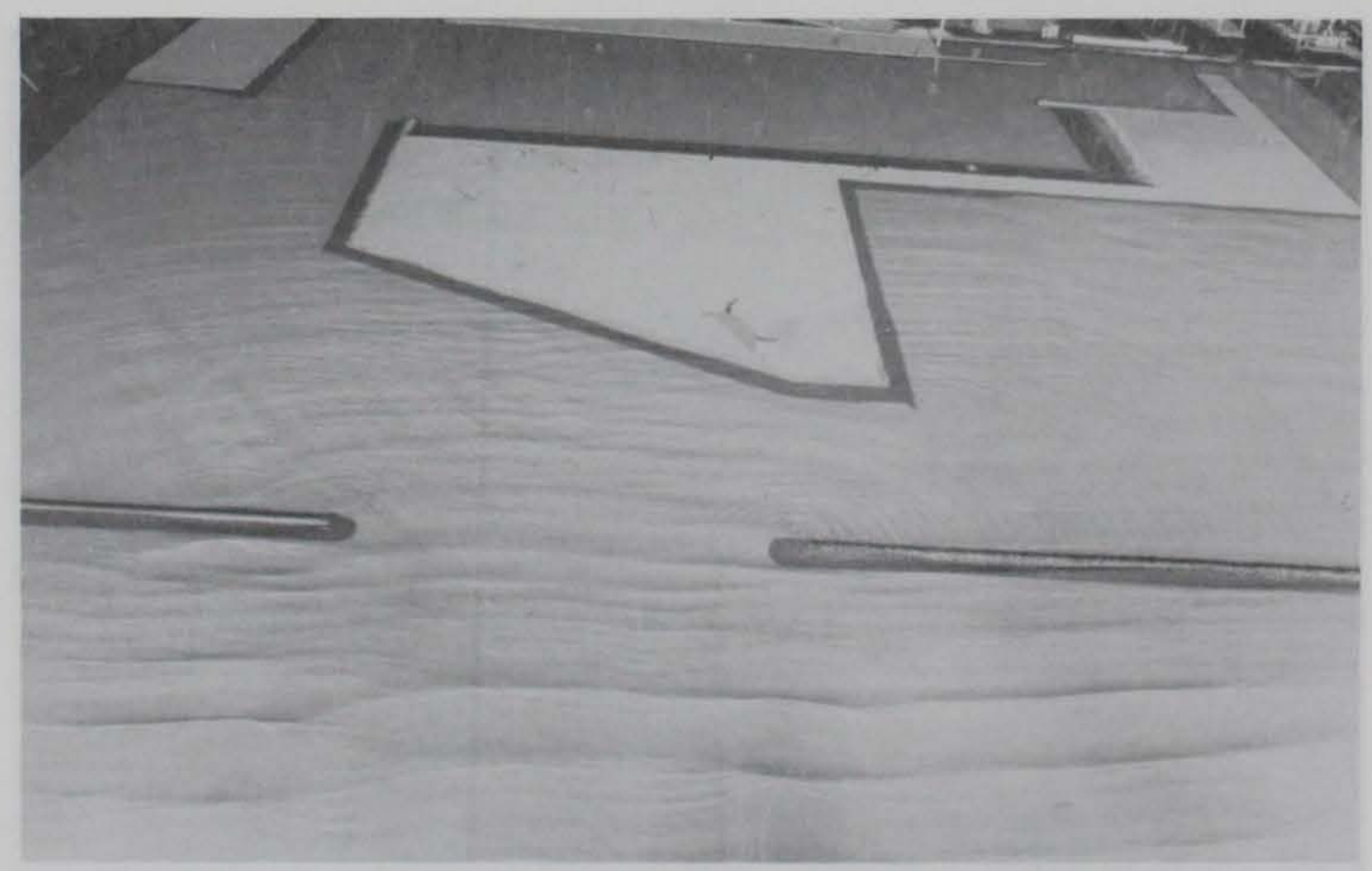

Photo 16. Typical wave patterns for Plan 14;

$11-\mathrm{sec}, 10-\mathrm{ft}$ waves from $154 \mathrm{deg}$ 


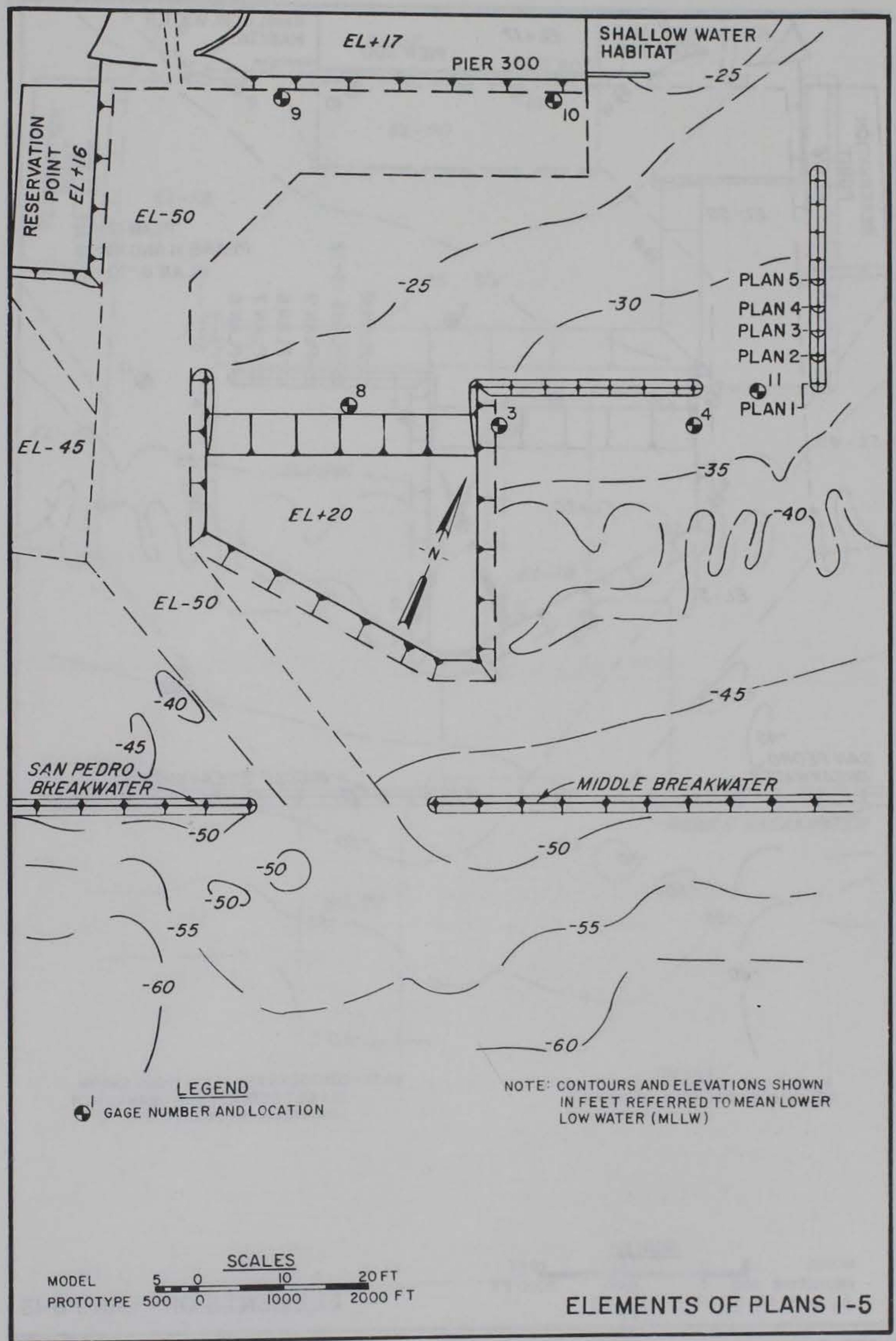




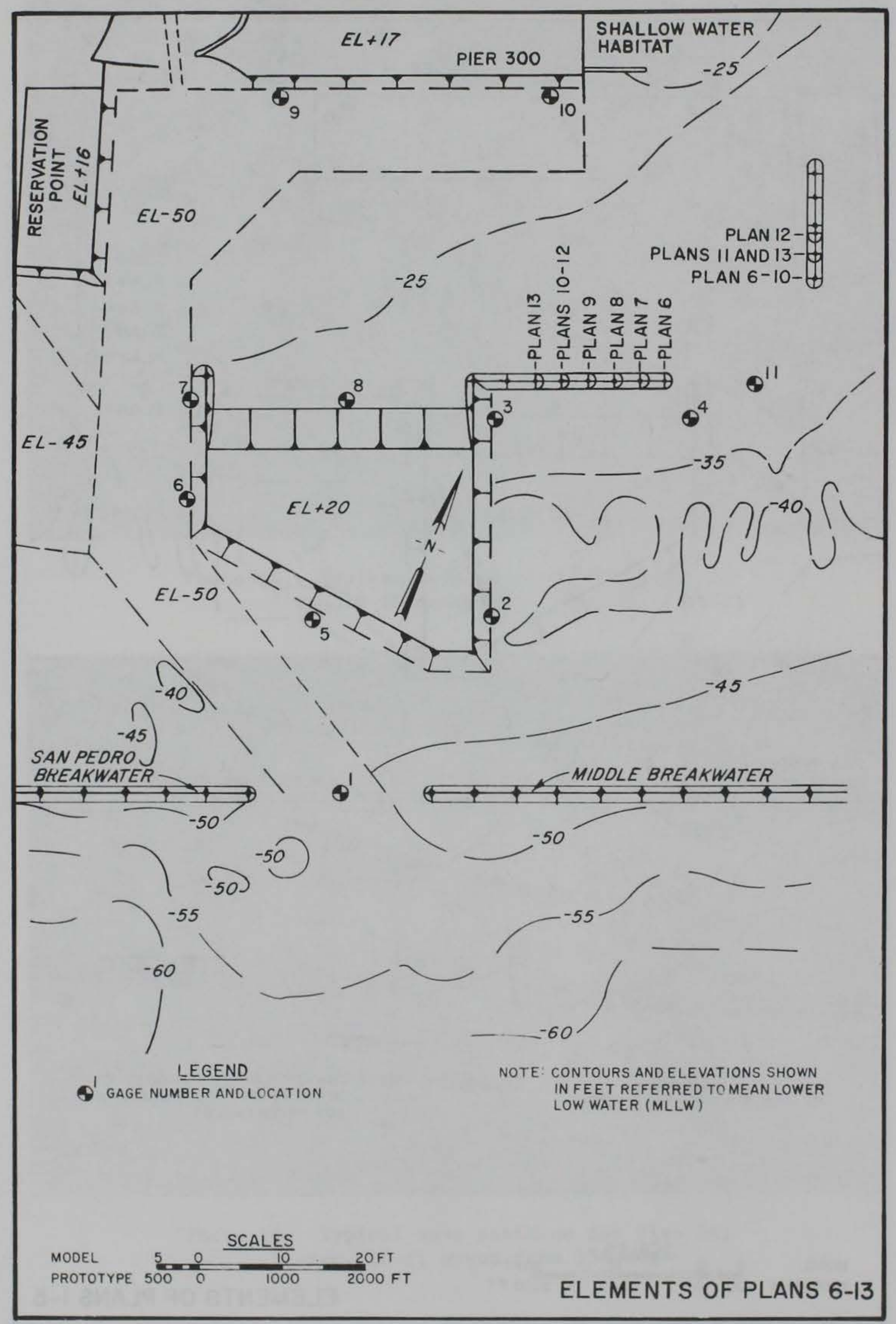

PLATE 2 


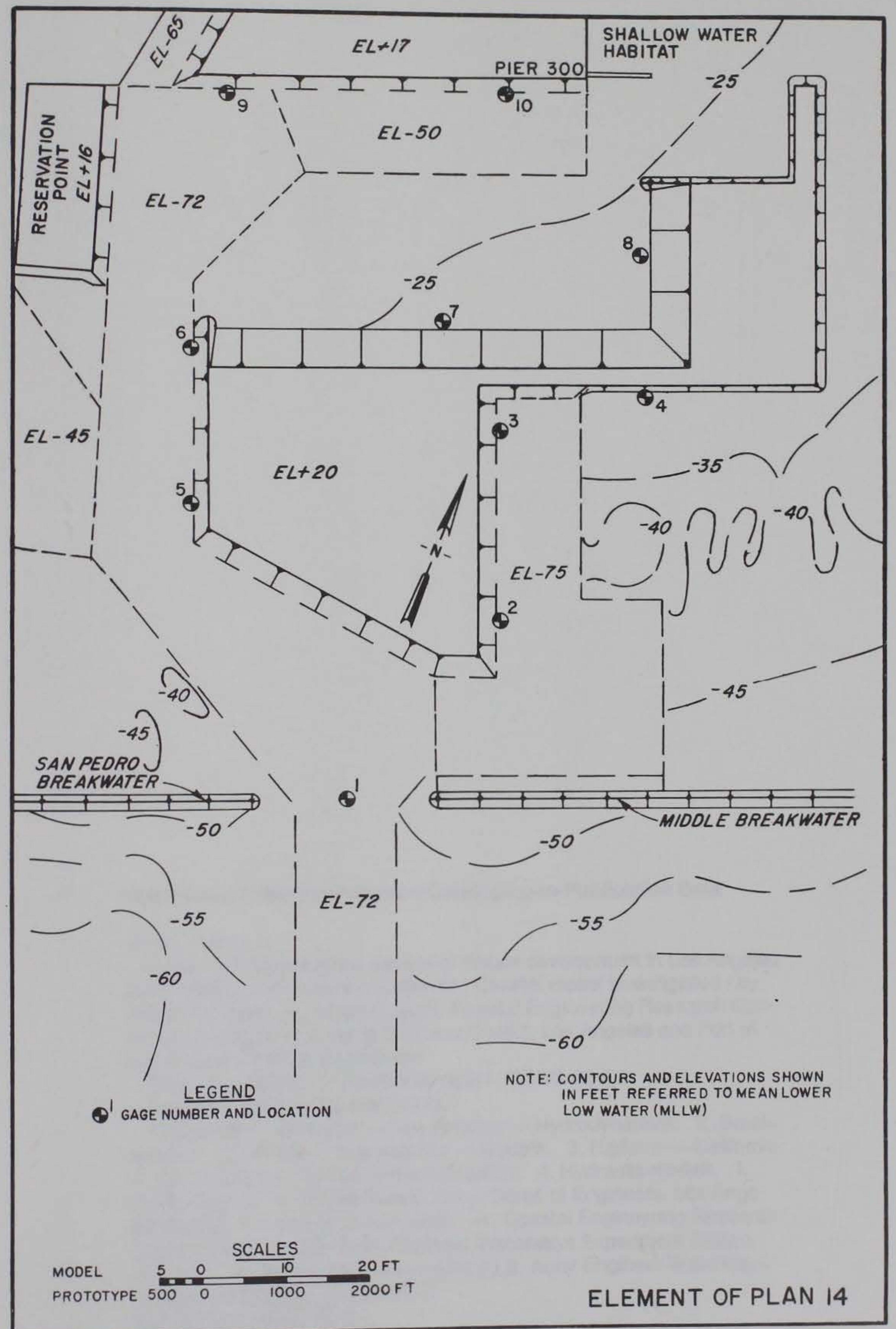


Bottin, Robert R.

Wave conditions for two phases of harbor development in Los Angeles outer harbor, Los Angeles, California : Coastal model investigation / by Robert R. Bottin, Jr., Hugh F. Acuff, Coastal Engineering Research Cen: ter ; prepared for U.S. Army Engineer District, Los Angeles and Port of Los Angeles, Harbor Department.

53 p. : ill. ; $28 \mathrm{~cm}$. - (Technical report ; CERC-92-6)

Includes bibliographic references.

1. Harbors - California - Los Angeles - Hydrodynamics. 2. Breakwaters - California - Los Angeles - Models. 3. Harbors - California - Los Angeles - Design and construction. 4. Hydraulic models. I. Acuff, Hugh F. II. United States. Army. Corps of Engineers. Los Angeles District. III. Port of Los Angeles. IV. Coastal Engineering Research Center (U.S.) V. U.S. Army Engineer Watenways Experiment Station. VI. Title. VII. Series: Technical report (U.S. Army Engineer Waterways Experiment Station) ; CERC-92-6.

TA7 W34 no.CERC-92-6 